\title{
Assessment of the African Airborne Dust Mass Over the Western Mediterranean Sea Using Meteosat Data
}

\author{
François Dulac, ${ }^{1}$ Didier Tanré, ${ }^{2}$ Gilles Bergametth ${ }^{3}$ Patrick Buat-Ménard, ${ }^{1}$ Michel. Desbois,${ }^{4}$ \\ AND DAVID SUTTON ${ }^{1,5}$
}

\begin{abstract}
The mass of African dust present over the westem Mediterranean during a transport episode from northwestern Africa, which occurred in carly July 1985, is estimated using a desert aerosol model, an Earthatmosphere radiative transfer model and Metcosat visible channel data from $\mathbf{4}$ days running. Dust pixels are selected from Meteosat images, and their aerosol optical thickness is retrieved. A proportionality factor between aerosol optical thickness and atmospheric columnar aerosol loading is computed and applied to the dust pixels. The total mass of atmospheric particles over the basin is obtained by interpolation and spatial integration. The maximum aerosol optical thickness is 1.8. The maximum aerosol columnar loading is evaluated to be $2.3 \mathrm{~g} \mathrm{~m}^{-2}$. The integrated mass of particles present at a given time is estimated to raise up to about $0.6 \times 10^{12} \mathrm{~g}$ at the maximum and the total mass of dust exported from Africa to be of the order of $10^{12} \mathrm{~g}$. The method is carefully evaluated and uncentainties are discussed, with particular emphasis on the relationship between atmospheric dust mass and aerosol optical depth. The overall uncertainty on the total mass is roughly a factor \pm 3 . In the absence of clouds it appears that the major uncertainty results from the lack of knowledge of the actual mass-size distribution of suspended dust particles, pointing out the lack of relevant data on particles larger than $10 \mu \mathrm{m}$ in diameter. A simple calculation based on results from both computations and simultaneous field measurements yields a net transfer velocity of particles from the dust layer of approximately $1 \mathrm{~cm} \mathrm{~s}^{-1}$.
\end{abstract}

\section{INTRODUCTION}

Atmospheric fallout has been recognized to significantly influence the trace element biogeochemistry in the ocean [Buat-Menard and Chesselet, 1979; Martin and Fitzwater, 1988; Knap et al., 1990]. Previous studies in the western Mediterranean have shown that atmospheric transport of soil dust from Africa is responsible for sporadic but intense aerosol concentration peaks, with daily mean values greater than background by up to 2 orders of magnitude [Arnold et al., 1982; Chester et al., 1984; Tomadin et al., 1984; Dulac et al., 1987; Bergametti et al., 1989a; Corregiari et al., 1990]. These events control the atmospheric input to the sea of major particulate elements, such as $\mathrm{Al}, \mathrm{Si}$, or $\mathrm{Fe}$ [Bergametti et al., 1989b], and play a significant role in the $p H$ of associated precipitations [Loÿe-Pilot et al., 1986; Losno et al., 1988; Glavas, 1988]. Moreover, they are followed by significant increases of

\footnotetext{
${ }^{1}$ Centre des Faibles Radioactivités, Centre National de la Recherche Scientifique/Commissariat l'Energie Atomique, Gif-sur-Yvette, France.

${ }^{2}$ Laboratoire d'Optique Atmosphérique, Université des Sciences et Techniques de Lille, France.

${ }^{3}$ Laboratoire de Physico-Chimie de l'Atmosphère, Universite de Paris VII, France.

${ }^{4}$ Laboratoire de Météorologie Dynamique, Ecole Polytechnique, Palaiseav, France.

${ }^{5}$ Now at Department of Computer Science, Birkbeck College, London, England.
}

Copyright 1992 by the American Geophysical Union.

Paper number 91JD02427.

0148-0227/92/91JD-02427\$05.00 elemental concentrations and fluxes in the upper water column [Buat-Ménard et al., 1989]. Unfortunately, accurate transport and deposition estimates are troublesome to obtain on a regional scale because they require observations over extended time and space scales. Long term ground sampling experiments, performed in various oceanic regions, have also shown that annual atmospheric fallout of mineral dusts are governed by a few rainfall events [Uematsu et al., 1985; Bergametti et al., 1989b; Prospero, 1990].

Satellite observations offer an opportunity to make spatial extrapolations of local ground measurements, meteorological satellites being of particular interest for long term and large scale studies. It was recognized early on that remote sensing techniques could be used to detect desert dust clouds [Fujita, 1970; Prospero et al., 1970; Shenk and Curran, 1974], and satellite data have often been used for qualitative investigations of movements and source areas of individual dust plumes [e.g., Oliva et al., 1983; Iwasaka et al., 1983; Legrand et al., 1985; Coudé-Gaussen et al., 1897; Bergametti et al., 1989 b], or for long-term assessment of frequencies and source regions of dust transports [Middleton et al., 1986; Jankowiak and Tanré, 1992]. Moreover, it has been shown that aerosol optical depths may be derived from visible (VIS) or infrared (IR) satellite data [Griggs, 1975, 1979; Carlson, 1979; Kästner et al., 1983; Tanré et al., 1988 a; Haggerty et al., 1990; Tanré and Legrand, 1991]. Observations in the visible range over the ocean allow more accurate estimations due to the low value of oceanic surface albedo. For instance, over the last few years, global maps of aerosol optical thickness over the oceans have been produced and distributed on a weekly basis [Rao et al., 1988]. Such data are particularly useful to meteorologists and atmospheric physicists. However, up to now, very few attempts have been made to derive the mass of aerosols being transported. Such information would be extremely useful when assessing the geochemical significance of such transport and deposition events, especially over open ocean areas. 
Measurements of aerosol mass from satellite data were first reported by Fraser [1976], who derived the desert dust columnar atmospheric density over the ocean off northwestern Africa from multispectral MSS Landsat data. Fraser et al. [1984] estimated the columnar atmospheric density of particulate sulfur over polluted areas of the United States from the aerosol scattering coefficient derived from GOES data. Desert aerosol mass was also estimated from aerosol optical thickness derived from Landsat data offshore from Israel [Mekler et al., 1977] and from GOES data offshore from the Arabian peninsula [Sirocko and Sarnthein, 1989]. The method consists in using a mathematical relationship between the aerosol mass density in a vertical column and an optical parameter such as radiance [Fraser, 1976], aerosol scattering coefficient [Waggoner and Weiss, 1980], or aerosol optical thickness [Carlson and Caverly, 1977], derived from the satellite signal using an Earth-atmosphere radiative model.

In this paper we focus on the use of Meteosat data to estimate the mass of desert dust over the western Mediterranean, with special reference to a dust transport event which occurred in early July 1985 and for which ground-based measurements were available. Aerosol optical depth over the basin is estimated from Meteosat VIS data using an Earth-atmosphere radiative transfer model, and a relationship between aerosol optical depth and aerosol mass is computed. Uncertainties are evaluated and discussed. Finally, the transfer velocity of particles from the dust layer is evaluated from the computed aerosol atmospheric loading and ground deposition sampling measurements.

\section{The Data Base}

\subsection{Satellite Data}

Digital data from both visible (VIS: $0.35-1.1 \mu \mathrm{m}$ ) and thermal infrared (IR: 10.5-12.5 $\mu \mathrm{m}$ ) channels of the operational meteorological satellite Meteosat 2 were obtained from the European Space Operation Center, Darmstadt, Germany. A sequence of 8 VIS and 8 IR images have been considered, corresponding to Meteosat slot 24 (1100-1130 UT observation) and slot 25 (1130-1200 UT observation) on July $1-4,1985$. Data were coded over 8 bits, so that numerical values were integers ranging between 0 and 255 . We modified the VIS data by setting its two least significant bits to zero. This was done because VIS data consist of a 6-bit signal to which an extra 2 bits, whose value is random, have been added for technical reasons [European Space Operation Center (ESOC), 1987]. Our modified VIS data thus have values ranging from 0 to 252 in steps of 4 .

The resolution of full Earth disk images is 5000 columns by 2500 lines in the VIS channel and 2500 by 2500 in the IR. We resampled the VIS images to make them coincident with the IR images, by sampling one column in every two of VIS data. We used windows of 510 pixels $\times 510$ lines, approximately centered on Algiers, and covering Spain, southern France, Italy, the westem Mediterranean, and northwestern Africa.

\subsection{Field Sampling and Analytical Methods}

Atmospheric aerosol samples were collected at Capo Cavallo $\left(42^{\circ} 31 \mathrm{~N}, 8^{\circ} 40 \mathrm{E}\right)$, Corsica. The sampling site has an unimpeded view of the sea, is $700 \mathrm{~m}$ from the shore, and at an altitude of about $300 \mathrm{~m}$. Noon-to-noon daily aerosol samples were collected between February 1985 and December 1987, at the top of a 10 -m-high meteorological tower, on $0.4 \mu \mathrm{m}$ porosity Nuclepore filters [Remoudaki, 1990]. Samples of total deposition (wet plus dry) were also collected there during the same period, on a 10- to 20-day basis, using a hemispheric collector with an area of $0.1 \mathrm{~m}^{2}$. The deposition samples were acidified using $\mathrm{HNO}_{3} \mathrm{O} .1 \mathrm{~N}$ and filtered on $0.4 \mu \mathrm{m}$ porosity Nuclepore ${ }^{(1 i l t e r s . ~ D e t a i l s ~ o f ~ s a m p l i n g ~ l o c a t i o n ~ a n d ~}$ conditions have already been published elsewhere [Bergametti, 1987; Bergametti et al., 1989a; Dulac et al., 1989]. We shall focus here on the late June-early July 1985 period, during which a transport of dust particles from Africa was recorded [Bergametti et al., 1989b]. Data include (1) daily atmospheric concentrations of $\mathrm{Al}, \mathrm{Si}$, and $\mathrm{Fe}$, from June 21-22 to July 1011, excluding two missing samples on June 27-28 and July 9. 10; and (2) Si total deposition, integrated from June 21, 1100 , to July 1,1000 , from July 1,1000 , to July 11,1140 , and from July 11, 1140, to August 1,1000 . It rained during the first deposition sampling period but the two other samples consisted only of dry deposition.

Xray fluorescence was used for $\mathrm{Al}, \mathrm{Si}$, and $\mathrm{Fe}$ analyses of aerosol samples [Losno et al., 1987], and for $\mathrm{Si}$ in the undissolved fraction of total deposition samples. Analytical precision was better than $\pm 5 \%$ for the samples considered here. Si concentration in the filtered solution was determined from total deposition samples by colorimetry, with a precision of about $\pm 10 \%$ [Bergametti, 1987].

\subsection{Meteorological Data}

Conventional data. Basic meteorological parameters (wind velocity and direction, cloud coverage, precipitation) were recorded at intervals of 6 hours at Capo Cavallo, which used to be a French meteorological station. Vertical profiles of temperature and relative humidity from the ground level up to $500 \mathrm{hPa}$ (about $5900 \mathrm{~m}$ ), from July 1 to 7,0000 and 1200 UT, were obtained from rawindsonde soundings of the atmosphere performed at the Corsican meteorological station of Ajaccio $\left(41^{\circ} 55 \mathrm{~N}, 08^{\circ} 48 \mathrm{E}\right)$.

Air mass trajectories. In order to trace back the transport of aerosol particles from their source regions, air mass trajectories have been computed by the Service des Etudes Spéciales, Météo-France, Paris [Martin et al., 1987; Bergametti et al., 1989a; Martin et al., 1990]. Three-dimensional, 4-day back trajectories, finishing at the sampling point and at the midtime of each daily sampling time and arriving at the 925-, 700-, and $500-\mathrm{hPa}$ final levels, have been computed from the analyzed wind fields of the European Center for Medium-Range Weather Forecasts in Reading, England. Forward trajectories leaving the source region, as identified from Meteosat data, were also computed.

\section{Algortrims aNd Methods}

\subsection{Cloud Discrimination}

Because of the high albedo of clouds, aerosol optical thickness should be inferred from cloud-free pixels. Applying a simple adjusted multispectral threshold on VIS and IR counts is insufficient to discriminate cloud-covered pixels, so that more complex tests are necessary [Schiffer and Rossow, 1983; Saunders and Kriebel, 1988]. The reason is that comparable VIS brightnesses are produced by intense aerosol loading and by 
semi-transparent or partial cloud coverage, and comparable IR radiative temperatures are produced by dust and water clouds present at comparable altitudes. However, Coackley and Bretherton [1982] have shown that water or ice clouds and dust clouds may be discriminated by differences in local standard deviation of pixel values, determined over square areas of some pixels. This is due to the difference in spatial homogeneity of water and dust clouds.

In order to detect cloudy pixels we applied an objective discrimination method, based on four different threshold tests. The first three were respectively applied to the VIS count, to the IR count, and to the VIS local variance calculated over a 3 by 3 pixel area. Respective threshold values were optimized by visual examination of the images so that evident cloudcontaminated pixels were marked out, and pixels at the limit between homogeneous areas of dust pixels of different luminances were saved. Pixels were discarded as cloudy when (1) their VIS count was greater than 60 , which otherwise would have lead to aerosol optical thickness values greater than 3.5 ; (2) their IR count was lower than 120 , corresponding to a radiative temperature lower than $5^{\circ} \mathrm{C}$ according to the IR sensor calibration [Meteosat Exploitation Project (MEP), 1985]; and (3) their VIS variance was greater than 8. This spatial coherence test was the most severe one, as verified by Jankoviak and Tanré [1992] from Meteosat data over the Atlantic. Only a few likely cloud pixels in large scale cloud structures and in scattered cloud fields were not discarded. However, these few pixels appeared to have a significant influence when interpolating pixel values over masked areas (see section 3.3 on integration over the basin). We discarded these pixels using an edge filter which retains a pixel $P$ if at least six of the pixels adjacent to $P$ have the same value as $P$ and eliminates $P$ otherwise.

\subsection{Retrieval of the Aerosol Optical Depth Over the Sea}

Earth-atmosphere radiative transfer model. Because of relatively high values of land albedos in the visible the apparent reflectance is only slightly modified by atmospheric aerosol so that it is not easy to extract the aerosol content over land from the satellite signal. Moreover, the value of these albedos is difficult to assess precisely at the scale of Meteosat pixels, due to their geographical and temporal variability. On the other hand, surface seawater has a low and fairly constant albedo. So we retrieved aerosol optical depth only over the sea, from Meteosat VIS data, and using an Earth noncloudy atmosphere radiative model derived from the computer code "Simulation of the Satellite Signal in the Solar Spectrum" (5S), available from the Laboratoire d'Optique Atmosphérique, Université des Sciences et Techniques de Lille, France [Tanré et al., 1986, 1990]. Briefly, this computer code allows the estimation of the satellite signal due to the backscattering of the light in the solar spectrum by the ground-atmosphere system, assuming a cloudless atmosphere. It includes accurate analytical descriptions of the absorption by aerosol particles and atmospheric gases $\mathrm{H}_{2} \mathrm{O}, \mathrm{O}_{3}, \mathrm{O}_{2}$, and $\mathrm{CO}_{2}$, and of the scattering by gas molecules and aerosols, as well as an approximate handling of the interaction between the two phenomena. The apparent reflectance as seen by the satellite is expressed as a function of the intrinsic atmospheric reflectance, the actual target reflectance, and the ground reflectance outside the target, which may be different. The relative contributions of the direct and diffuse transmittances on the sun-ground and ground-satellite paths, of the spherical albedo of the atmosphere and of the environment of the target, are calculated as well as the transmission multiplicative factor related to the absorption by atmospheric gases and particles.

Input parameters include geometrical and spectral conditions, atmospheric gaseous composition, aerosol type and concentration, and ground reflectance. Our geometric and spectral conditions were defined by Meteosat 2 position and filter function [Morgan, 1981]. The VIS channel has a nonzero transmission between 0.35 and $1.1 \mu \mathrm{m}$, with a spectral integrated value of 0.39 . The standard mid-latitude summer atmosphere from the LOWTRAN code [Mc Clatchey et al., 1971; Kneizys et al., 1980] was used to define the gaseous composition of the atmosphere. Corresponding $\mathrm{O}_{3}$ and $\mathrm{H}_{2} \mathrm{O}$ columnar densities are 6.83 and $29300 \mathrm{~g} \mathrm{~m}^{-2}$, respectively. The spectral reflectance of seawater, as computed by model $5 S$ from data on the spectral dependence of clear seawater reflectance [Viollier, 1980], was 0.024 . This value may be questionable, and the resulting uncertainty will be emphasized in section 4.4.

Aerosol model. When running model 5S, the user can set the atmospheric aerosol composition by combining four basic components as defined in World Climate Programme (WCP) [1986]: continental dustlike, oceanic, nonoceanic water soluble, and soot. Each of these standard components is characterized by a monomodal lognormal distribution with respective geometric mean diameters of $1.0,0.6,0.01$, and $0.0236 \mu \mathrm{m}$. Ground measurements have shown that a dustlike component of the aerosol is quantitatively predominant in the case of transport of African dusts [Bergametti et al., 1989a]. However, aerosol particles in plumes transported from arid regions have different microphysical properties compared with other continental dustlike aerosol particles and can be clearly identified as desert aerosol [Jaenicke, 1987; Coudé-Gaussen, 1989]. Indeed, the optical properties of the WCP standard dustlike component [WCP, 1986] are significantly different from optical properties of desert aerosol [Shettle, 1984; D'Almeida, 1987]. Therefore we had to consider a specific desert aerosol component and to implement it in 5S.

Fitting data from seven cascade impactor samples of African dust performed in Corsica and at sea during several oceanographic cruises have yielded a single mode for particle size distribution, with a mass-median diameter (MMD) ranging from 2.3 to $5.2 \mu \mathrm{m}$ and a geometric standard deviation $(\sigma)$ ranging from 1.1 to 4.5 , the largest values being derived from samples collected along the African coast [Bergametti, 1987; Dulac, 1986; Dulac et al., 1989; Gomes et al., 1990]. However, our cascade impactors allow the sampling of particles in a limited range of size, probably from 0.05 to $15 \mu \mathrm{m}$ in diameter. Moreover, the optical properties of these aerosols have not been studied. Because of this lack of relevant data from African dust plumes over the Mediterranean we considered the standard continental desert aerosol models which were available from Shettle [1984] and D'Almeida [1987]. These authors have determined optical properties for several standard models of desert aerosol, based on measurements of number-particle size distributions and of refractive index. Size-distribution parameters used by Shettle relied on the compilation by Jaenicke [1987], while D'Almeida relied on his own measurements in Africa. The values of the refractive index in the visible range used by Shettle and D'Almeida stemmed from measurements performed on Saharan aerosols by Carlson and Caverly [1977] and Patterson et al. [1977]. In Table 1 are 
TABLE 1. Parameters of the Mass-Size Distributions of Desert Aerosol Models

\begin{tabular}{|c|c|c|c|c|}
\hline Acrosol Model & Mode & $\mathrm{MMD}, \mu \mathrm{m}$ & $\boldsymbol{\sigma}$ & $C, \%$ \\
\hline \multicolumn{5}{|c|}{ D'Almeida [1987] } \\
\hline \multirow[t]{3}{*}{ Background } & 1 & 0.832 & 2.10 & 3.6 \\
\hline & 2 & 4.82 & 1.90 & 95.7 \\
\hline & 3 & 19.38 & 1.60 & 0.7 \\
\hline \multirow[t]{3}{*}{ Wind-carrying dust } & 1 & 0.600 & 2.15 & 0.4 \\
\hline & 2 & 14.68 & 2.07 & 95.7 \\
\hline & 3 & 55.6 & 1.70 & 3.9 \\
\hline \multirow[t]{3}{*}{ Sandstorm } & 1 & 0.578 & 2.15 & $1.6 \times 10^{-2}$ \\
\hline & 2 & 37.2 & 2.50 & 15.7 \\
\hline & 3 & 90.0 & 1.80 & 84.3 \\
\hline \multicolumn{5}{|c|}{ Shettle [1984] } \\
\hline \multirow[t]{3}{*}{ Background } & 1 & 0.0110 & 2.13 & $2.6 \times 10^{-4}$ \\
\hline & 2 & 2.52 & 3.20 & 78.1 \\
\hline & 3 & 42.3 & 1.89 & 21.9 \\
\hline \multirow[t]{3}{*}{ Dust storm } & 1 & 0.0052 & 1.77 & $9.6 \times 10^{-9}$ \\
\hline & 2 & 468 & 5.89 & 32.6 \\
\hline & 3 & 456 & 2.74 & 67.4 \\
\hline \multicolumn{5}{|c|}{ This Work (From Cascade Impactor Data) } \\
\hline \multicolumn{5}{|c|}{ Dust event in northwestem } \\
\hline Mediterranean & 1 & 2.50 & 2.0 & 100.0 \\
\hline
\end{tabular}

MMD: mass-median diameter, $\sigma$ : standard deviation; $C$ : contribution to the total mass.

presented the mass-particle size distribution parameters that we calculated from the number distributions they selected, assuming spherical particles of density $2.5 \mathrm{~g} \mathrm{~cm}^{-3}$. Each proposed model is composed of three lognormal modes, and it can be seen in Table 1 that there are significant differences in the mass-size distribution parameters of the different modes between comparable models by Shettle and D'Almeida. This is also the case for the total distributions when the three modes are summed. A monomodal model of the size distribution of desert dust particles over the northwestem Mediterranean during transport events from Africa is also suggested for comparison in Table 1, from our cascade impactor samples.

Results in Table 1 show that the mass-particle size distribution of the background desert aerosol model used by Shettle [1984] seems well adapted to our observations, because it presents a single mode in the particle size range where cascade impactors efficiently collect particles. This mode accounts for $78.1 \%$ of the total particle mass. There is no reason to believe that the submicronic mode observed in source areas is not transported in the dust plume [e.g., Schütz, 1979]. However, the contribution of this mode to both aerosol mass and optical properties is negligible. On the other hand, there is observational evidence that giant mineral particles (of diameter $50 \mu \mathrm{m}$ or more) from desert areas are transported over very long distances [Prospero et al., 1970; Jaenicke and Schütz, 1978; Carder et al., 1986; Betzer et al., 1988; Coudé-Gaussen, 1989]. Microscopic investigations of aluminosilicate particles in aerosol samples [Coude-Gaussen, 1989] and in a dry deposition sample [Dulac et al., 1991] from Corsica also indicate that large particles are present in African dust plumes over the
Mediterranean. Dulac [1986] reported an overall MMD of about $13.5 \mu \mathrm{m}$ for insoluble particles in a red rain collected at sea $\left(40.62^{\circ} \mathrm{N}-07.17^{\circ} \mathrm{E}\right)$ in April 1981. Pitty [1968] also reported a MMD of $9 \mu \mathrm{m}$ for such particles in a red rain collected in Britain in July 1968, while Bücher and Lucas [1975] reported MMDs of about 10 and $5.3 \mu \mathrm{m}$, respectively, in two red snows collected in the French Pyrenees in February 1972 and in March 1974, with $25 \%$ of the total deposited mass in particles greater than 34.7 and $13.3 \mu \mathrm{m}$, respectively. Moreover, using a Coulter ${ }^{(8)}$ counter, Guerzoni et al. [1991] measured mass-particle size distributions from a few rain and aerosol samples associated with southern origins, which were collected in southeastern coastal Sardinia. Their results suggest an overall MMD of about $15 \mu \mathrm{m}$ in two different rain samples and the presence of two modes in one aerosol sample. These modes are at about 3 and 15 $\mu \mathrm{m}$ in diameter, and the large mode contribution to the total mass is about $40 \%$. The background aerosol model used by Shettle states that the relevant large mode has a MMD of 42.2 $\mu \mathrm{m}$ and accounts for $22.1 \%$ of the total mass (Table 1). Any location in the western Mediterranean basin is within $1500 \mathrm{~km}$ of the North African source region of dust for the episode considered (see section 4.1). Schütz's [1979] calculations, which consider only particles in the diameter range $0.2-40 \mu \mathrm{m}$, suggest that particles larger than $20 \mu \mathrm{m}$ in diameter can contribute significantly to the total aerosol concentration in this range of distance from Saharan source areas. Therefore in the absence of more quantitative data on very large particles we assumed that the particle size distribution of the background desert aerosol model used by Shettle [1984] was suitable for desert aerosols transported over the western Mediterranean. The 
relevant size distribution used by Shettle is based on a model for a remote continental environment [Jaenicke, 1987]. Long range transport of the dust cloud over the sea might allow the modification of the original, dust storm type, size distribution toward a background type of distribution. Indeed, according to experts [WCP, 1983] the aerosol over deserts in the absence of dust storms resembles that of remote continents. Moreover, the radiative properties of this aerosol model, derived using Saharan dust refractive index, are in good agreement with optical ground-based measurements performed in Senegal during dust events [Tanré et al., 1988b]. The radiative properties of $D^{\prime}$ Almeida's [1987] background model were also very consistent, and the consequence of using either mass-size distribution will be emphasized in section 4 .

Aerosol optical depth. All other parameters being fixed, the aerosol optical thickness at $550 \mathrm{~nm}\left(\tau_{550}\right)$ was used to set the aerosol concentration, assuming that the atmospheric aerosol loading is directly related to $\tau_{550}$. The approach we used was to look at the variations in the calculated Meteosat signal when varying $\tau_{550}$, in order to fit the spectral aerosol optical depth dependence as a function of the Meteosat value for a given geometry.

The radiance at the top of the atmosphere $\left(L^{*}\right.$, in $\left.\mathrm{W} \mathrm{m}^{-2} \mathrm{sr}^{-1}\right)$ has been computed using the radiative properties of the aerosol model and the modified version of the $5 S$ code, for several values of $\tau_{550}: 0.1,0.2,0.4,0.6,0.8,1.0,1.2,1.4,1.7,2.0$, and 2.5. The corresponding Meteosat value $(N$, a real positive number) was retrieved from $L^{*}$, as calculated by $5 S$, using the following equation:

$$
N=2+L^{*} / C
$$

where $C=0.575 \mathrm{~W} \mathrm{~m}^{-2} \mathrm{sr}^{-1} 8$-bit-count $\mathrm{H}^{-1}$ is the calibration constant of the Meteosat 2 VIS channel determined by Köpke [1983].

If we consider only single scattering of light then the aerosol optical thickness could be expressed analytically as

$$
\tau=4 \pi L^{*} \cos \left(\theta_{v}\right) / E_{0} P\left(\theta_{s}\right)
$$

where $\theta_{v}$ is the zenith viewing angle, $E_{0}$ the solar irradiance at the top of the atmosphere, and $P\left(\theta_{s}\right)$ the phase function for a scattering angle $\theta_{s}$. This would allow us to express $\tau$ as a function of $N$ as follows:

$$
\begin{gathered}
\tau=a_{0}+a_{1} N \\
a_{0}=-8 C \pi \cos \left(\theta_{v}\right) / E_{0} P\left(\theta_{s}\right) \\
a_{1}=4 C \pi \cos \left(\theta_{v}\right) / E_{0} P\left(\theta_{s}\right) .
\end{gathered}
$$

The coefficients $a_{0}$ and $a_{1}$ depend on the geometrical conditions (hour of observation and position of the pixel). In fact, however, a more accurate calculation was performed, which took multiple scattering into account in a simple way, and a third-order polynomial function was fitted between $\tau_{550}$ and $N$ :

$$
\tau_{550}=a_{0}^{\prime}+a_{1}^{\prime} N+a_{2}^{\prime} N^{2}+a_{3}^{\prime} N^{3} \text {. }
$$

Geometrical conditions corresponded to $\mathrm{mid}$ day observations (specifically at 1145 and 1215 UT (corresponding to Meteosat slot 24 and 25, respectively) from July 1 to 4 ) and to 35 test pixels regularly distributed throughout the western Mediterranean area. Corresponding $\theta_{v}$ ranged between $42^{\circ}$ and $52^{\circ}$, while the sun zenith angle ranged between $13^{\circ}$ and $23^{\circ}$.

Moreover, for each image from the series considered (hour of observation fixed), the coefficients $a_{i}(0 \leq i \leq 3)$ were fitted as

$$
a_{i}=b_{0, i}+b_{1, i} A,
$$

where $A$ is the angle between $O C$ and $C P$ if $O, C$, and $P$, respectively, are the point of $0^{\circ}$ latitude and $0^{\circ}$ longitude, the center of the Earth, supposed spherical, and the point of observation, and each $b_{0, i}$ and $b_{1, i}$ a constant for that particular image.

The accuracy of the overall fit of $\tau_{550}$ in function of $N$ and $A$ was checked. Any test value of $\tau_{550}$ was approximated to within \pm 0.015 . The relative precision was better than $1 \%$ for $\tau_{550} \geq 0.6$. The highest deviations between fitted and computed values were observed for $\tau_{550}=0.1$ at the far southwest and northeast of the basin for slot 24 (maximum relative deviation of $4.5 \%$ ) and at the far southeast for slot 25 (maximum $8.5 \%$ ).

\subsection{Airborne Dust Mass}

Columnar aerosol mass loading at the pixel scale. It is generally accepted that the aerosol optical thickness at a wavelength $\lambda\left(\tau_{\lambda}\right)$ is proportional to the total aerosol mass loading $\left(M\right.$, in $\left.\mathrm{g} \mathrm{m}^{-2}\right)$ in a vertical column [Volz, 1970; Carlson and Caverly, 1977]:

$$
M=R \tau_{\lambda}
$$

where the proportionality factor $R$ depends on aerosol properties. The mass $M$ depends on the aerosol size distribution $n(r, z), r$ being the radius of particles, supposed spherical, and $z$ the altitude, and on the aerosol density $d$

$$
M=(4 / 3) \pi d \int_{0}^{\infty} d z \int_{0}^{\infty} r^{3} n(r, z) d r
$$

while $\tau_{\lambda}$ depends on the aerosol size distribution $n(r, z)$ and on the Mie theory extinction cross section $Q$, itself depending on the aerosol particle size $r$ and refractive index $m$, and on the wavelength $\lambda$,

$$
\tau_{\lambda}=\pi \int_{0}^{\infty} d z \int_{0}^{\infty} r^{2} Q(m, r, \lambda) n(r, z) d r .
$$

Assuming a particle density of $2.5 \mathrm{~g} \mathrm{~cm}^{-3}$ [Fraser, 1976; Carlson and Caverly, 1977], a particle refractive index of 1.55 $0.005 i$ [Patterson et al., 1977] and a constant size distribution as a function of the altitude, we computed the ratio $R_{550}$ between $M$ and $\tau_{550}$, the aerosol optical thickness at $\lambda=550$ nm, for the five desert aerosol distribution models from Shettle [1984] and D'Almeida [1987]. Results are reported in Table 2. The large spread of the results shows that the determination of $M$ from $\tau_{550}$ is very sensitive to the aerosol mass-size distribution and therefore subject to large uncertainties. The computed value of 1.3 is in good agreement with the values of 1.3 and 1.5 reported for Saharan aerosol after Atlantic crossing, by Volz [1970] and by Carlson and Caverly [1977], respectively, after measurements in the Caribbean and at Barbados. When only the intermediate mode of Shettle's background model is considered, the ratio $R_{550}$ is 0.965 (Table 2). This value is $26 \%$ lower than when considering the three modes together, when $22 \%$ of the mass is due to the single third mode (Table 1). This confirms that extinction is essentially due to the second mode, while the third mode also contributes significantly to the total mass. We also determined the value of $R$ for the model derived from cascade impactor Mediterranean samples of African aerosol presented in Table 1. The result is 1.13 (Table 2) and consequently very close to relevant values 
TABLE 2. Ratio $R_{550}$ Between the Total Aerosol Mass in an Atmospheric Column and the Aerosol Optical Thickness at $550 \mathrm{~nm}$ for Desert Aerosol Distribution Models

\begin{tabular}{lc}
\hline \multicolumn{1}{c}{ Aerosol Model } & $R_{550}=M\left(\mathrm{~g} \mathrm{~m}^{-2}\right) / \tau_{550}$ \\
\hline D'Almeida [1987] & 2.4 \\
Background & 8.2 \\
Wind carrying dust & 45.1 \\
Sandstorm & \\
Shettle [1984] & 0.965 \\
Background, mode 2 & 1.3 \\
Background & 135.6 \\
Dust storm & \\
This Work & 1.13 \\
Dust event in northwestem Mediterranean & \\
\hline
\end{tabular}

derived from Shettle's background model. As already mentioned, Shettle's background model fits our ground measurements, which cover a limited range of particle size, so that the value of 1.30 seems the most realistic one. Therefore we used the following relationship to infer the columnar atmospheric dust loading from the atmospheric turbidity:

$$
\mathrm{M}\left(\mathrm{g} \mathrm{m}^{-2}\right)=1.3 \tau_{550}
$$

For comparison, let us also mention the value of 3.75 measured by Carlson and Caverly [1977] at Cape Verde Islands (off the West African coast) and the value of about 10, deduced from measurements performed by D'Almeida [1986] at Agadez assuming the thickness of the equivalent homogeneous Saharan air layer was $3 \mathrm{~km}$. Although all these coefficients are deduced from optical thicknesses determined for different spectral conditions, the authors agree that the dependence of $\tau$ on $\lambda$ is weak in the case of desert aerosol [Carlson and Caverly, 1977; Shettle, 1984; D'Almeida, 1987] so that the different values of the ratio $R$ from the literature may be compared to the value of $R_{550}$ calculated in this work.

Integration over the basin. The aerosol columnar densities were determined from a limited number of pixels, due to the presence of islands and clouds over the basin. In order to take into account the mass of dust present in the numerous pixels where raw data were not exploitable in terms of aerosol loading, we performed a linear interpolation of the discontinuous $M$ fields. This is justified because the continuity of aerosol densities through areas that were masked suggest that water clouds did not significantly modify the structure of the dust front (Plate 1). Indeed, the meteorological reports from Ajaccio confirmed the presence of a partial coverage of the sky $(<50 \%)$ by altocumulus clouds, but only over $2500 \mathrm{~m}$ (the highest altitude of the standard scale used for reports) during the passage of the cloud system over Corsica (July 4, 0000 and 1200 UT reports), while clear sky was observed on the day before and after.

We used a standard distance weighted interpolation routine of the Uniras ${ }^{\otimes} /$ Unimap $^{2000^{(}}$graphic display package [UNIRAS, 1988, 1989]. The grid cell for interpolation was fitted to have one pixel per grid node. No smoothing of interpolated data was performed, so that the numerical values of unmasked pixels remained unchanged after the interpolation process.

\section{Results and Discussion}

\subsection{Atmospheric Circulation}

The Meteosat images displayed in Plate 1 have been simply colored in order to show the transport of a dust plume from North Africa to Europe over the western Mediterranean, associated with the eastward movement of a cyclonic cloud system over the basin. With a view to a better understanding of the atmospheric processes involved in this dust production and transport event, it is necessary to briefly describe the mesoscale meteorological situation. The meteorological charts reported in Figure 1 are based on the meteorological synoptic charts from the European Meteorological Bulletin. The $850 \mathrm{hPa}$ chart in Figure 1a shows the incursion of a cold polar air mass over the eastern Atlantic at the latitude of the Iberian peninsula. An anticyclonic wedge was located over Tunisia and the southern part of the western Mediterranean Sea. Ground level charts report a NW-SE front, between the trough located over the eastern Atlantic and this anticyclonic wedge, generating strong winds ahead of itself in northeastem Algeria. The evolution of the $850 \mathrm{hPa}$ situation on July 3 and 4 is reported in Figures $1 b$ and $1 c$. The eastward movement of the trough, which was located over the Iberian peninsula on July 3 , generated a SW-NE circulation at $850 \mathrm{hPa}$ in the westem part of the western Mediterranean, propitious to dust transport from North Africa to the basin. Simultaneously, the front also moved eastward and was located over Corsica and Sardinia on July 4. Meteorological reports from Ajaccio and Capo Cavallo did not mention any precipitation during the passage of the front.

A high pressure center was located over the gulf of Gabes and northern Tunisia, which generated a W-E circulation over the central Mediterranean. Hence the SW-NE transport of the western part of the dust cloud, as visible in Plate 1, was due to the cyclonic flow generated by the trough located over the Iberian peninsula, while the eastern part of the dust cloud was transported eastward under the influence of the high pressure cell located over Tunisia.

Backward air mass trajectories, finishing at our ground sampling station at Capo Cavallo, on July 4, at 700 and 925 $\mathbf{h P a}$, are reported in Figure 2. They clearly show that the upper air mass, transported from Africa to Corsica, experienced a mean continuous upward movement from the source region, over a lower layer air mass coming from the Atlantic over France. This is in agreement with the frontal character of African dust transport events over the westem Mediterranean and western Europe [Prodi and Fea, 1979; Reiff et al., 1986; Bergametti et al., 1989a, Martin et al., 1990]. These trajectories suggest that the dust layer was transported at a mean altitude of about $3 \mathrm{~km}$ over Corsica. Moreover, rawindsonde soundings performed at Ajaccio showed that the thickness of the dust layer over Corsica was up to $5500 \mathrm{~m}$ on July 3,0000 $\mathrm{UT}$, and that an average thickness of about $3500 \mathrm{~m}$ may be assumed for the dust layer during its presence over Corsica (Table 3).

Only a rough indication of the source region of the dust is given by finishing trajectories (Figure 2). Meteosat IR images taken on July 1 and 2 show that a dust rise occurred on the Algerian Atlas plateaus (Plate 2), which has extensive areas of dried marshes in summer [Peters, 1989]. Indeed, the dust rise on July 1, as visible in plate 2, was limited to the chott Ech Chergui area. Two forward air mass trajectories have been computed, starting on July $2,0600 \mathrm{UT}$, at $850 \mathrm{hPa}$, from the 


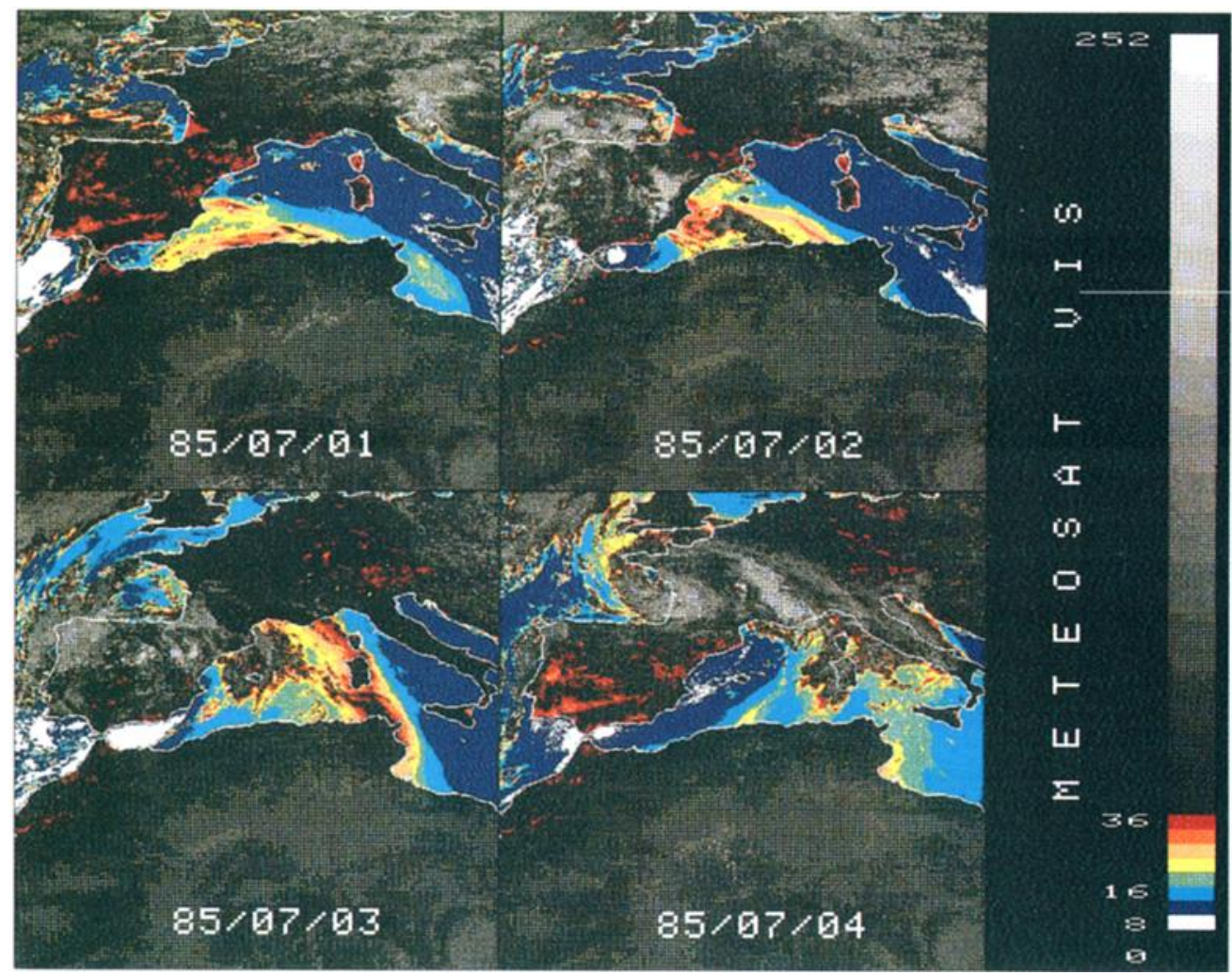

Plate 1. Colored Meteosat VIS images (July 1 to 4, 1985, slot 24) showing the transport of a dust plume over the western Mediterranean basin. Pixels with their numeric count at 8 (the lowest value in these images) are displayed in white, pixels at 12 in dark blue, pixels at 16 in light blue, .... pixels at 36 in red. Pixels with upper values are black and white shaded. (Photo European Space Agency and Centre des Faibles Radioactivités).
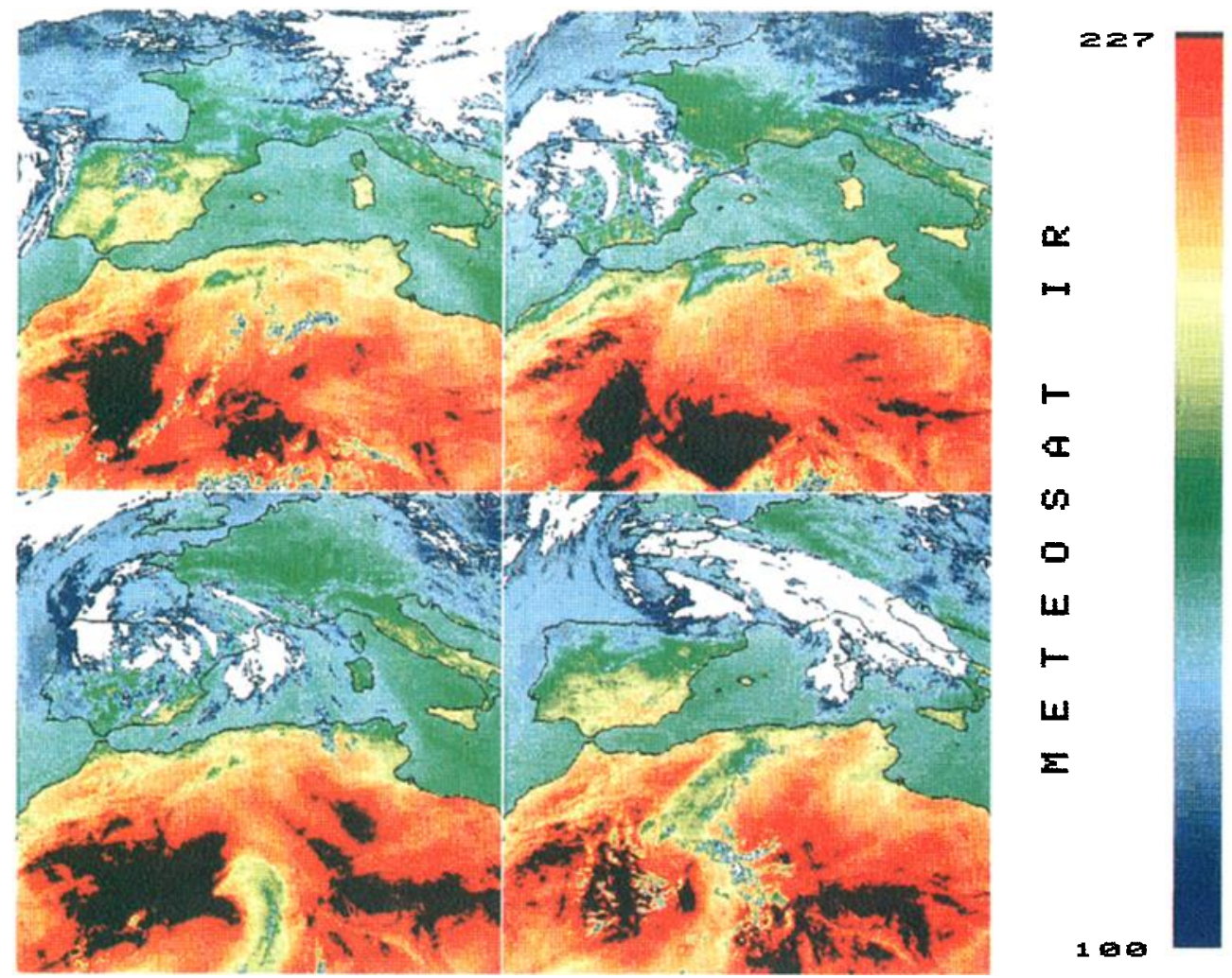

Plate 2. Colored Meteosat IR images (July 1 to 4,1985, slot 24) showing the dusts over Africa (in green). The dust source region is visible in northem Algeria on July 1 and 2 . A dust plume coming from the south is visible on July 3 and 4 . The color table is linearly distributed between the numeric counts $100\left(-6.5^{\circ} \mathrm{C}\right)$ and $227\left(51^{\circ} \mathrm{C}\right)$. Pixels with their counts in the outer range are thresholded in white (cold) and black (warm).(Photo European Space Agency and Centre des Faibles Radioactivités). 
eastern and western borders of the source region as observed on the satellite IR image (Plate 2). The starting barometric level of $850 \mathrm{hPa}$ was chosen to be representative of the altitude of the Atlasic high plains in the considered region. These two trajectories are reported in Figure 3. They are consistent with the outlines of the dust cloud during its transport over the western Mediterranean, as deduced from meteorological charts (Figure 1) and seen on Meteosat VIS images (Plate 1).

\subsection{Ground-Based Measurements}

Daily atmospheric concentrations. The atmospheric particulate concentrations of $\mathrm{Al}$ or $\mathrm{Si}$ are well known to be efficient tracers of the soil-derived dust component of the tropospheric aerosol [Rahn, 1976]. The daily atmospheric particulate concentrations of $\mathrm{Al}, \mathrm{Si}$, and $\mathrm{Fe}$ at Capo Cavallo from June 2122 to July 12-13 are reported in Figure 4. During this period, mean background levels were observed (about $300 \mathrm{ng} \mathrm{m}^{-3}$ for $\mathrm{Al}$ and $\mathrm{Fe}$ and about 1000 for $\mathrm{Si}$ ). These correspond to the typical summer background levels in this part of the western Mediterranean, as observed by Bergametti et al. [1989a]. However, the samples collected on July 2-3 to July 5-6 exhibit much higher concentrations, up to $5900 \mathrm{ng} \mathrm{m}^{-3}$ for Si on July 4-5. Such high atmospheric concentrations of soil-derived dust in this area are generally connected to African dust inputs [Chester et al., 1984; Dulac et al., 1987; Bergametti et al., 1989a; Correggiari et al., 1990]. Rawind soundings at Ajaccio showed that changes in $\mathrm{Al}$ and $\mathrm{Si}$ concentrations were strongly correlated to changes in tropospheric air temperature. This is illustrated in Figure 5 where the temperature of air at the altitude of $2000 \mathrm{~m}$ is plotted together with the noon-to-noon daily atmospheric Si concentration at Capo Cavallo.

It is noteworthy that the concentration peak at the ground level corresponded to the July 4-5 sample (Figure 4), when the dust layer had already passed Corsica (Figure 5 and Plate 1). In contrast the maximum integrated dust load over Corsica seemed to have occurred during the sampling time of the previous sample, i.e., July 3-4. This is probably due to the frontal character of the dust transport. Indeed, the observation of dust at the ground level in Corsica when the dust layer was still at high altitude, on July $2-3$, may be attributed to strong vertical mixing in the frontal zone. Later, maximum concentrations at the ground level were observed. This was when the lowest part of the front passed over Corsica, allowing the presence of the dust layer at the sampling level. Results from the rawind soundings confirmed that the base of the warm and dry air layer regularly descended from about $550 \mathrm{~m}$ on July 3,0000 UT, to the sea level on July 4, 1200 UT (Table 3). This layer reached the level of the sampling station (about $300 \mathrm{~m}$ ) late on July 3 and was no longer present on July 5, 0000 UT. High concentrations, still observed on July 5-6, were probably due to the settling of particles.

The northward movement of another large dust cloud is visible over central Sahara on the July 3 Meteosat IR image (Plate 2). The Meteosat July 4 images (Plates 1 and 2) indicate that a secondary dust input occurred over the western Mediterranean from July 4. The neck of dust visible off Algeria on the July 4 VIS image (Plate 1) and still high $\mathrm{Al}, \mathrm{Si}$, and $\mathrm{Fe}$ atmospheric loading at Capo Cavallo on July 5-6 and 6-7 (Figure 4) suggest that this secondary dust plume could have

\subsubsection{5}

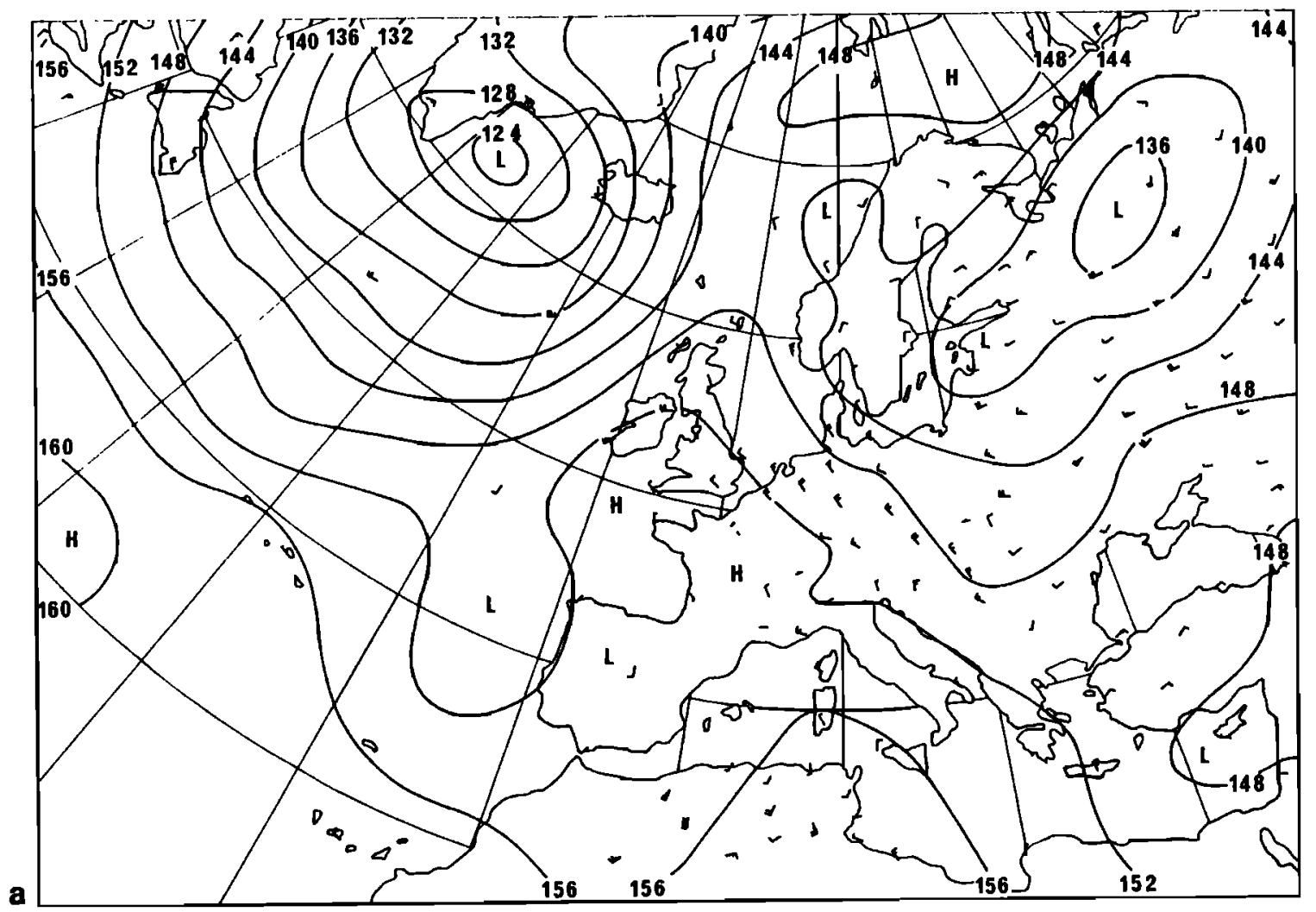

Fig. 1. Synoptic meteorological situation at $850 \mathrm{hPa}$ around the Mediterranean area on (a) July 2), (b) July 3, and (c) July 4, 1985. 
3.07.1985

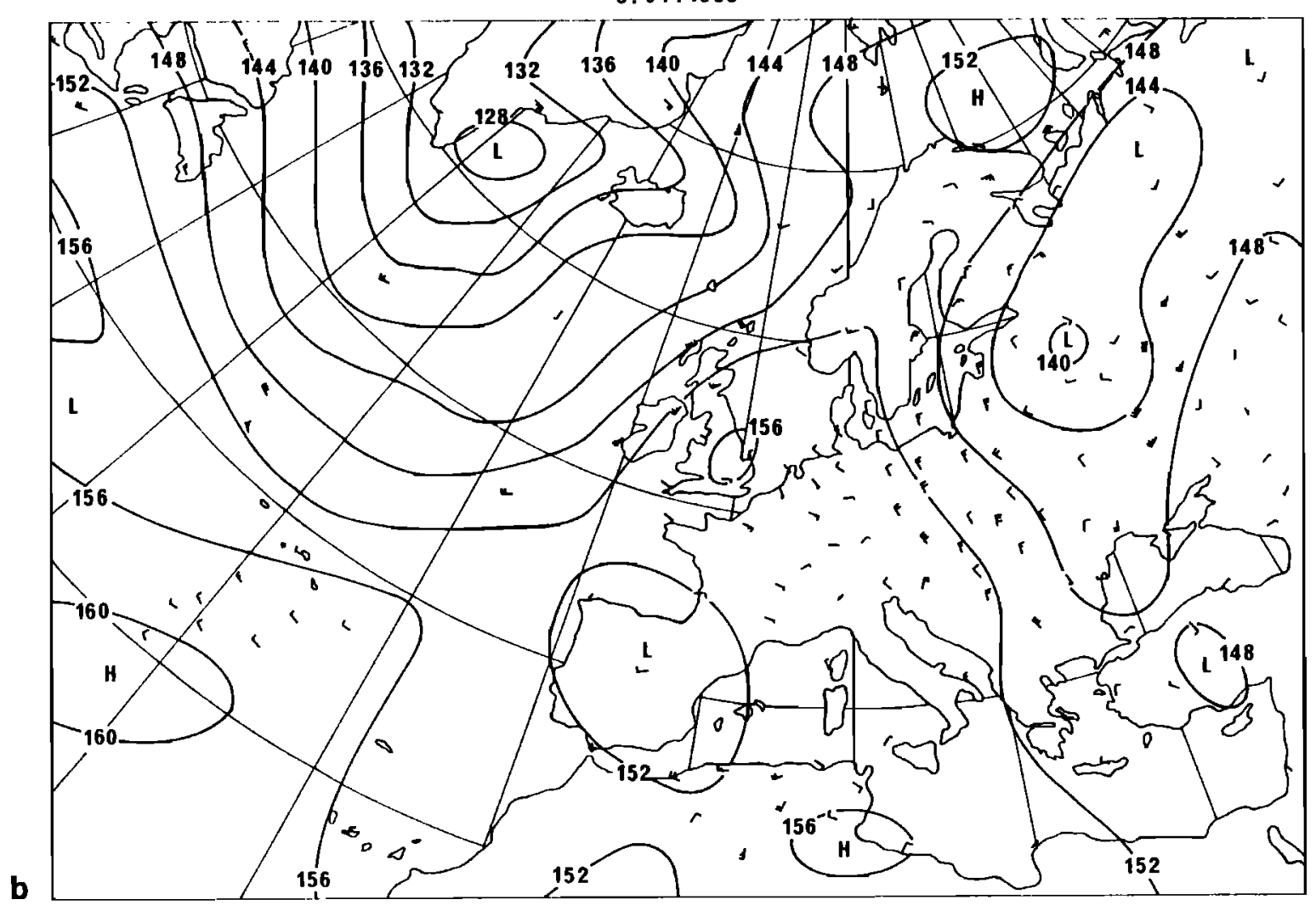

4.07.1985

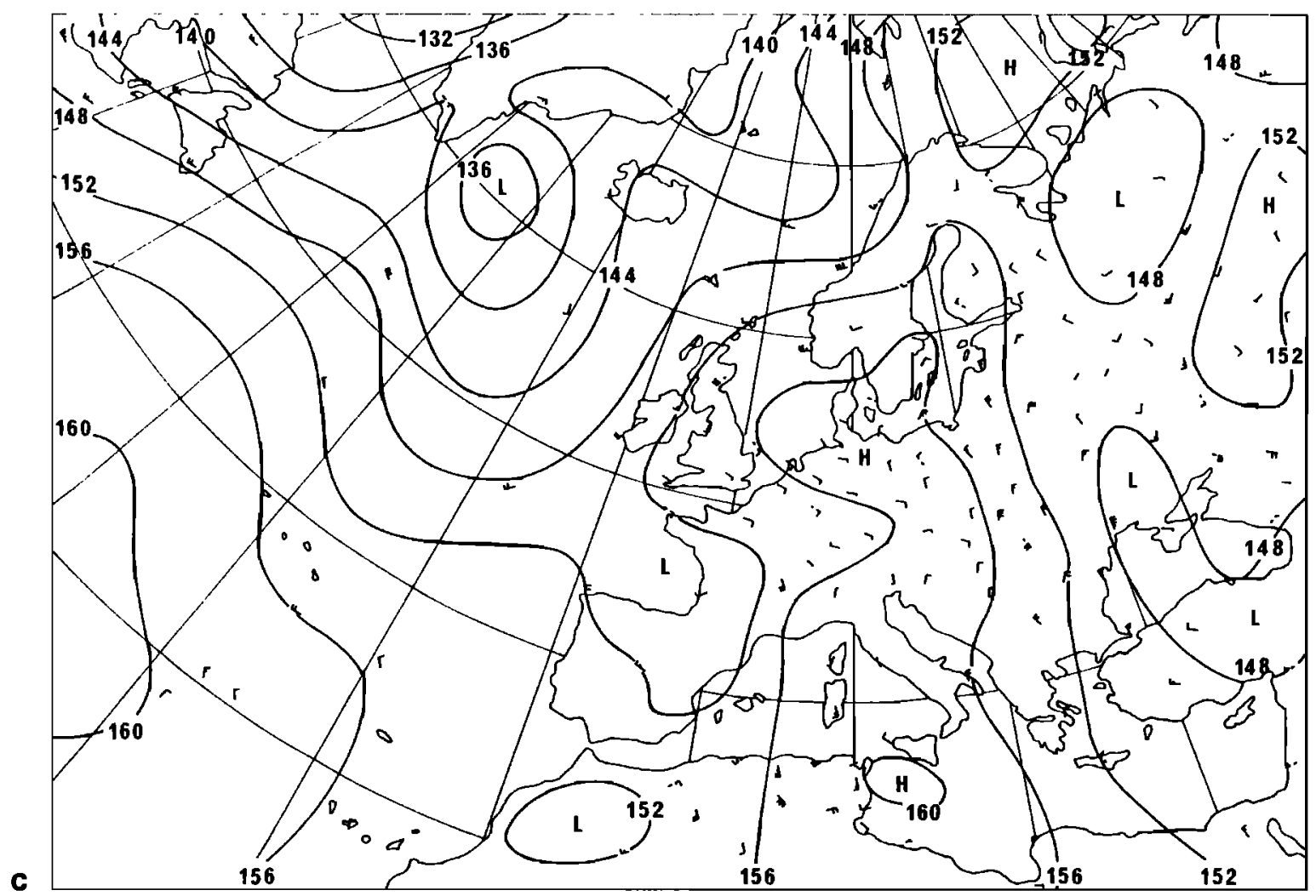

Fig. 1. (continued) 


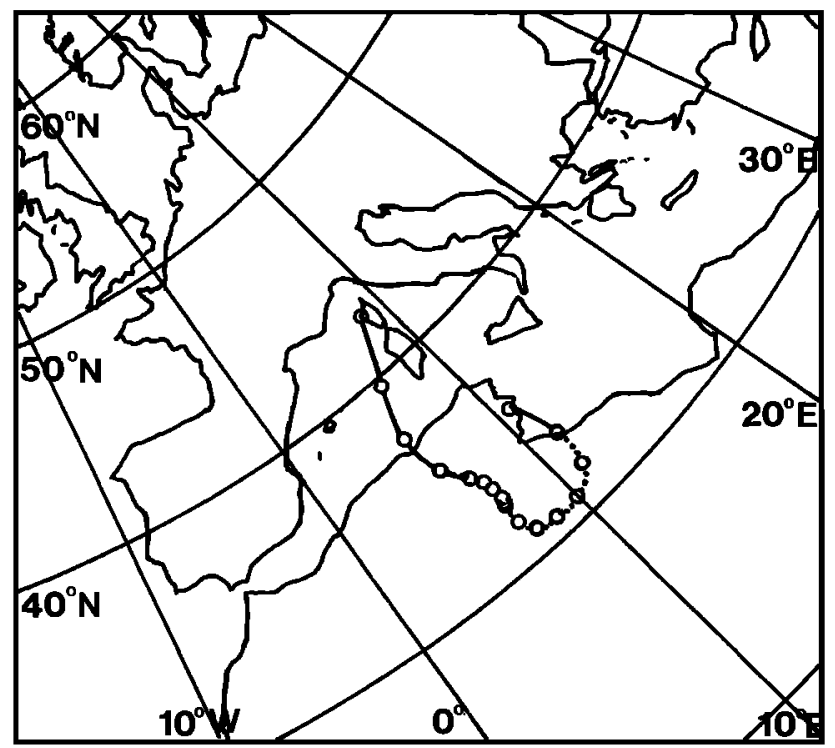

4.7.1985 $12 \mathrm{H}$

\section{$700 \mathrm{hPa}$}

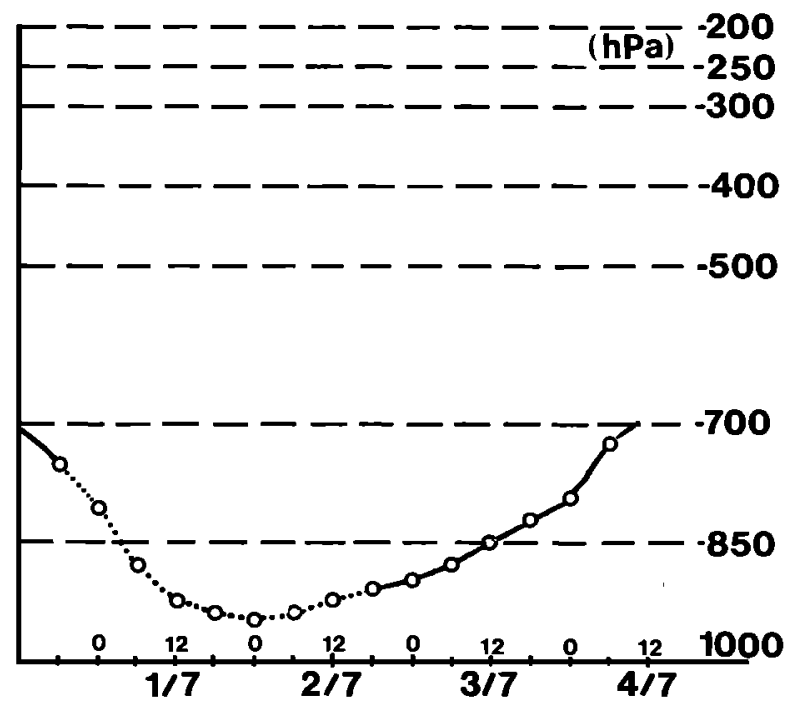

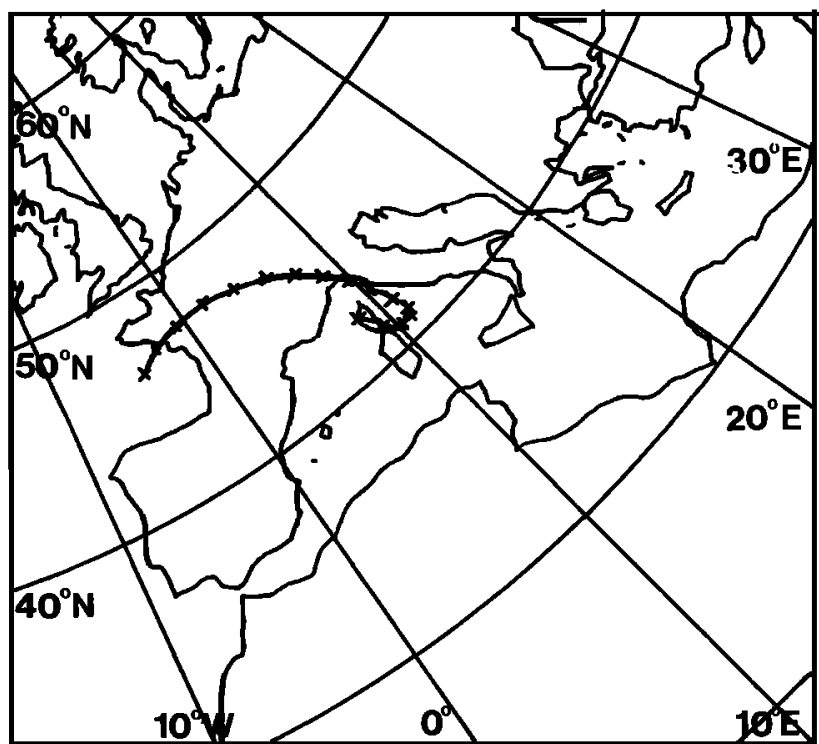

4.7.1985 $12 \mathrm{H} \quad 925 \mathrm{hPa}$

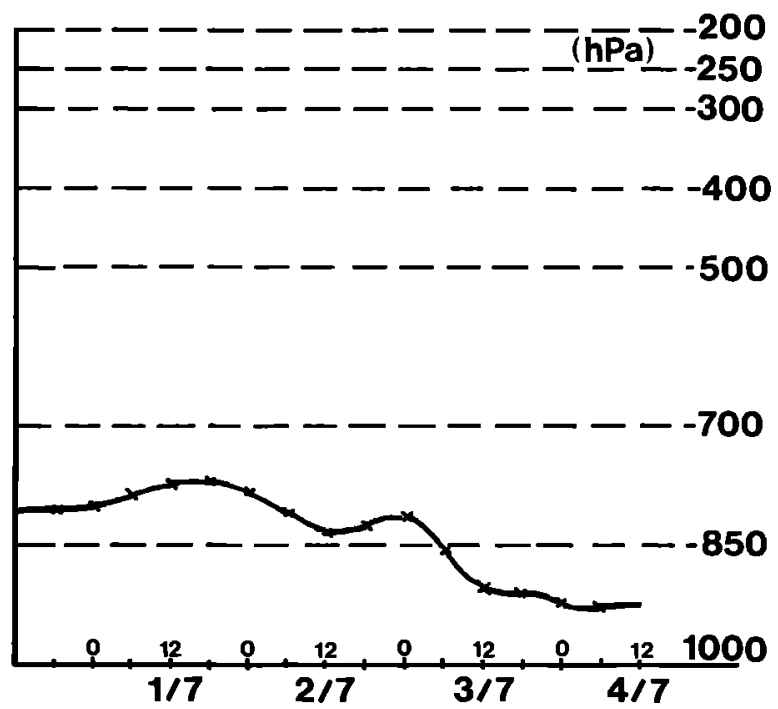

Fig. 2. Computed backward, three-dimensional air mass trajectories, ending at Capo Cavallo, at 1200 UT on July 4, 1985 , at 700 and $925 \mathrm{hPa}$. The time step between consecutive marks is 6 hours.

reached Corsica. Indeed, interelemental concentration ratios at Capo Cavallo showed a strong discontinuity between July 4-5 and July 5-6 samples. It has been shown that in the case of African dust transport in Corsica, characterized by high $\mathrm{Al}, \mathrm{Si}$, and $\mathrm{Fe}$ atmospheric concentrations, different source regions are characterized by different values of interelemental ratios in aerosol particles [Bergametti, 1987; Bergametti et al., 1989b]. While Si/Al and Fe/Al in July 2-3 to 4-5 aerosol samples were characterized by values typical for dust particles coming from Morocco and northwestern Algeria ( $\mathrm{Si} / \mathrm{Al}=2.64,2.82,2.77$; $\mathrm{Fe} / \mathrm{Al}=0.67,0.73,0.68$ ), the July 5-6 sample exhibited much higher values (3.45 and 1.12 respectively), encountered in Corsican samples of desert aerosol coming from more remote Saharan source regions [Bergametti et al., 1989b]. However, this secondary input was much more limited in intensity and spatial extension, as confirmed by examination of a spare Meteosat VIS image taken in the moming of July 5.
The evolution of atmospheric concentrations (Figure 4) and of the dust plume (Plate 1) suggest that the presence of atmospheric dust at Capo Cavallo lasted from early July 3 to early July 6, i.e., for $3 \pm 0.5$ days. In order to average the $\mathrm{Si}$

TABLE 3. Base Vertical Level and Thickness of the Warm and Dry African Air Layer Over Corsica, as deduced from rawindsonde soundings performed at Ajaccio

\begin{tabular}{lccc}
\hline Date & Hour, UT & Base, $m$ & Thickness, $m$ \\
\hline July 3, 1985 & 0000 & 540 & 5500 \\
July 3, 1985 & 1200 & 410 & 3500 \\
July 4, 1985 & $0000^{*}$ & 250 & $>2800$ \\
July 4, 1985 & 1200 & 0 & 3000 \\
\hline
\end{tabular}

* Upper data missing. 

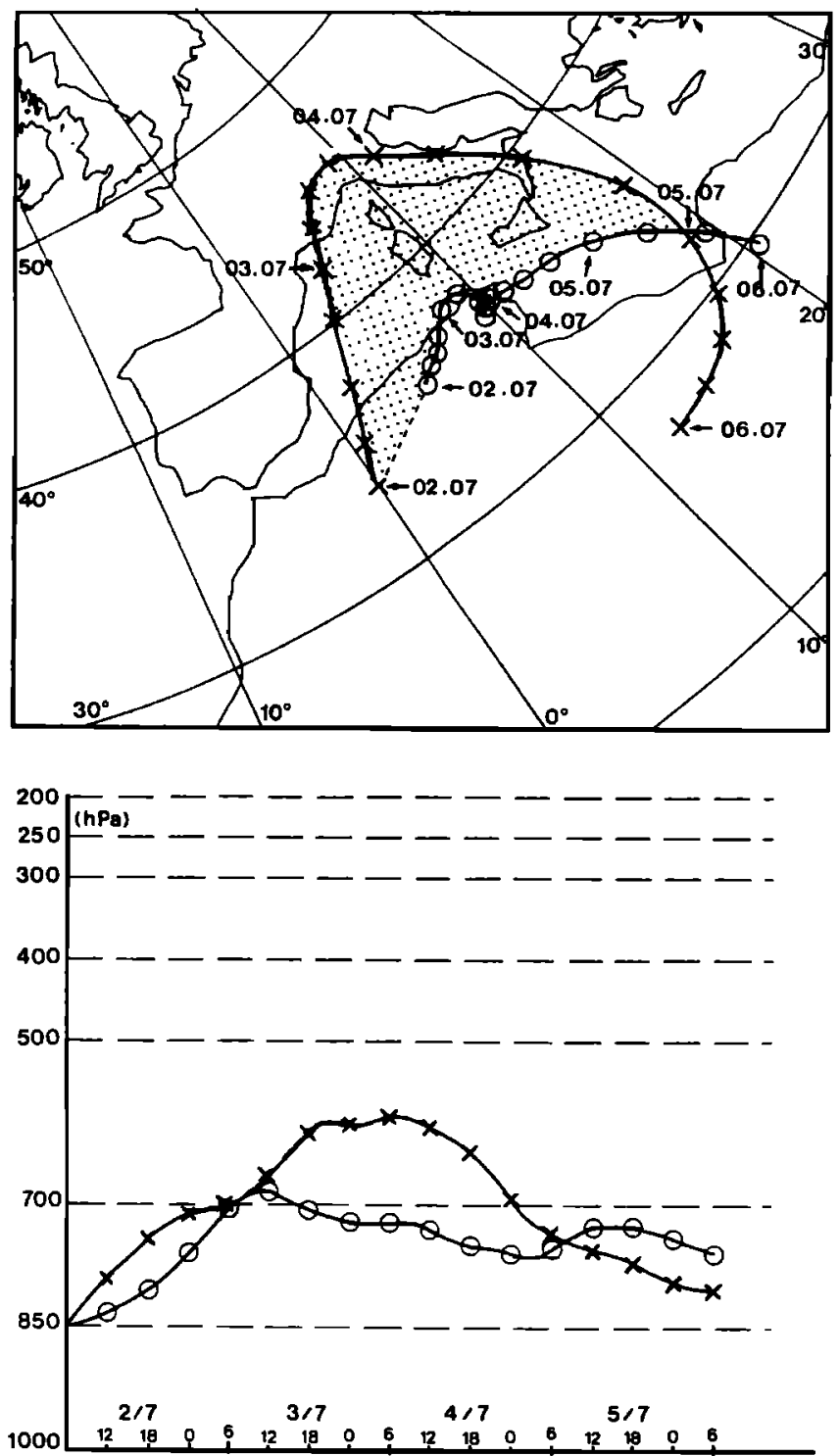

Fig. 3. Computed forward, three-dimensional air mass trajec-tories, leaving the eastem (0) and westem (+) boundaries of the dust source area at $0600 \mathrm{UT}$ on July 2,1985 , and at the $850 \mathrm{hPa}$ initial level. The time step between consecutive marks is 6 hours.

atmospheric concentration during that period and because of the noon-to-noon sampling period, we assumed background $\mathrm{Si}$ concentrations of 1000 and $1200 \mathrm{ng} \mathrm{m}^{-3}$, respectively, during the first half of the July 2-3 sampling period and the second half of the July 5-6 period (Figure 4). This yielded a mean atmospheric Si concentration of about $4900 \mathrm{ng} \mathrm{m}^{-3}$ over the 3 days of presence of dust particles over Corsica. Using the mean Si concentration of $33 \%$ in average soil [Vinogradov, 1959; Bowem 1966] as a reference for Si concentration in the aerosol, we estimated that an average concentration of dust of about $15000 \mathrm{ng} \mathrm{m}^{-3}$ occurred at the ground level during those 3 days.

Atmospheric deposition. The total atmospheric deposition of Si measured at Capo Cavallo during the sampling period considered was $(6.64 \pm 0.42) 10^{-3} \mathrm{~g} \mathrm{~m}^{-2} \mathrm{~d}^{-1}$ from June 21 to July 1 , (10.74 \pm 0.33$) 10^{-3} \mathrm{~g} \mathrm{~m}^{-2} \mathrm{~d}^{-1}$ from July 1 to July 11 , and $(3.13 \pm 0.13) 10^{-3} \mathrm{~g} \mathrm{~m}^{-2} \mathrm{~d}^{-1}$ from July 11 to August 1 . Precipitation was recorded at Capo Cavallo on June 22 (9 mm) and June 23 (traces), i.e., during the first deposition sampling

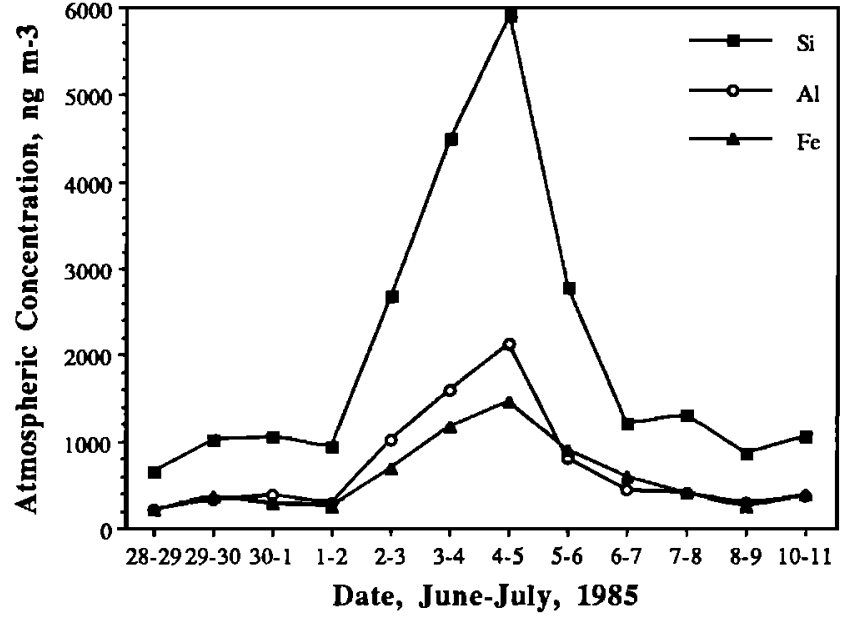

Fig. 4. Daily (noon to noon) mean atmospheric particulate concentrations of Si, Al, and Fe at Capo Cavallo between June 28-29 and July 10-11, 1985. The July 9-10 sample is missing.

period. The two other samples corresponded to dry deposition only. While comparable background concentrations of atmospheric particulate $\mathrm{Si}$ were observed during the first and third deposition samples, the deposition flux was twice as intense during the first sample as during the third, due to the wet deposition event. These results confirm that wet deposition is more efficient at aerosol deposition than dry deposition [Slinn, 1983]. Despite the absence of wet deposition but due to the occurrence of the dust event considered, the atmospheric deposition of Si was still higher for the second total deposition sample. Approximating the contribution of background $\mathrm{Si}$ deposition during this sampling period (10.12 days) from a mean atmospheric $S i$ concentration of $1000 \mathrm{ng} \mathrm{m}^{-3}$ and a dry deposition velocity of $1 \mathrm{~cm} \mathrm{~s}^{-1}$ for background conditions [Dulac et al., 1989], we calculated that a total of $0.10 \mathrm{~g} \mathrm{~m}^{-2}$ of Si was deposited due to the African dust plume itself. This corresponds to $92 \%$ of the $\mathrm{Si}$ deposition during the relevant total deposition sampling period. Using the mean $\mathrm{Si}$ concentration of $33 \%$ as a reference for $\mathrm{Si}$ concentration in the

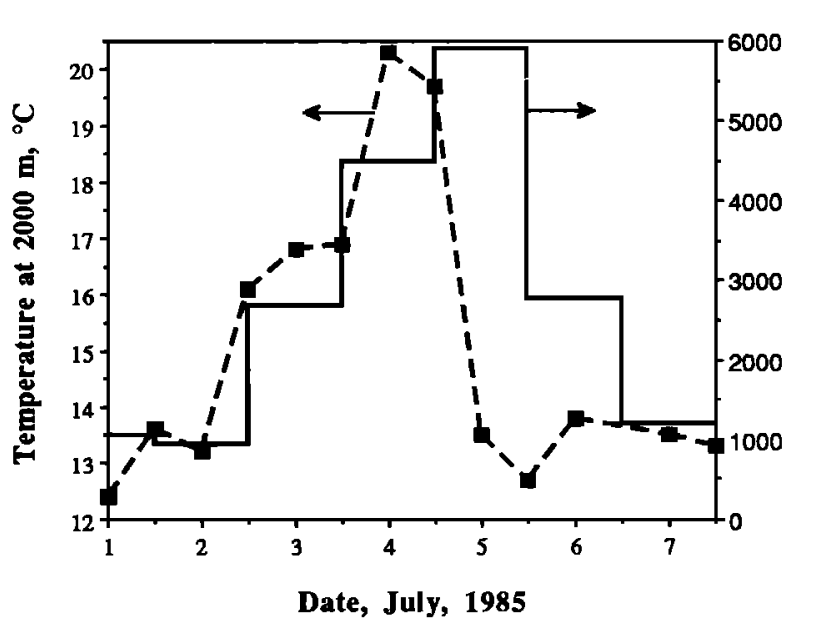

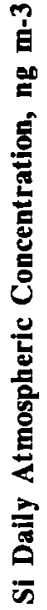

Fig. 5. Daily (noon to noon) mean atmospheric particulate concentration of $\mathrm{Si}$ at Capo Cavallo and air temperature at the altitude of $2000 \mathrm{~m}$ as deduced from available rawind soundings from July 1, 0000 UT, to July 7, 1200 UT. The July 6, 1200 UT, sounding is missing. 
deposited dust, we estimated that about $0.30 \mathrm{~g} \mathrm{~m}^{-2}$ of dust was deposited by dry deposition at the sea surface in the vicinity of Capo Cavallo, due to the African dust plume. Therefore an average deposition of dust of about $0.10 \mathrm{~g} \mathrm{~m}^{-2} \mathrm{~d}^{-1}$ occurred during the 3-day transit of the dust plume.

Deposition velocity of particles. From the previous estimates of the average atmospheric dust load and deposition at Capo Cavallo we inferred an average deposition velocity of the dust particles of $7.7 \mathrm{~cm} \mathrm{~s}^{-1}$ during the transit of the dust plume. In order to test our hypothetical aerosol model, we applied the Slinn and Slinn [1980] dry deposition model to the mass-particle size distribution of Shettle's background desert aerosol, divided into 100 successive size intervals, according to the method used by Arimoto et al. [1985] and discussed by Dulac et al. [1989]. This yielded a very consistent dry deposition velocity of dust particles to seawater of $6.9 \mathrm{~cm} \mathrm{~s}$, controlled by gravitational settling, with almost $94 \%$ of the deposition flux being due to the largest mode of the distribution (MMD is $42.2 \mu \mathrm{m}$, Table 1). The deposition velocity being particularly sensitive to the contribution of large particles [Dulac et al., 1989], the aerosol model of Shettle [1984] appears to be very well adapted to describe the whole massparticle size distribution of the dust particles transported during this event. Indeed, using the model for mass-particle size distribution from Mediterranean cascade impactor samples given in Table 1 yielded a dry deposition velocity of only 0.1 $\mathrm{cm} \mathrm{s}^{-1}$.

The same approach applied to the mass-size distribution of D'Almeida's background aerosol yielded a dry deposition velocity of dust particles to seawater of $0.4 \mathrm{~cm} \mathrm{~s}^{-1}$, more than 93\% of the flux being due to the intermediate mode (MMD is 4.82 $\mu \mathrm{m}$, Table 1). Previous studies in the western Mediterranean yielded $\mathrm{Al}$ dry deposition velocities from 1.1 to $9.7 \mathrm{~cm} \mathrm{~s}^{-1}$ in case of transport from Africa, averaging between 3 and $4 \mathrm{~cm} \mathrm{~s}^{-1}$ [Dulac et al., 1989]. Published deposition velocities for dust particles are generally close to $1 \mathrm{~cm} \mathrm{~s}^{-1}$ [Duce et al., 1980; Giorgi, 1988; Schneider et al., 1990] but these concern longer range and larger scale transport than in this study.

\subsection{Aerosol Optical Thickness}

Results. Plate 3 shows the calculated aerosol optical thickness $\left(\tau_{550}\right)$ over the western Mediterranean, at 1145 UT from July 1 to 4 . Values range from 0.14 to $1.77,0.14$ to 1.41 , 0.13 to 1.70 , and 0.14 to 1.04 , respectively, from July 1 to 4 . Similar results have been obtained at 1215 UT, using slot 25 . Because of the solar and viewing geometry the same Meteosat numeric count was produced by different aerosol optical thickness values in the northem and southern parts of the basin. On July 3 the front of the dust plume, extending from Tripoli, Libya, to the Gulf of Genoa, is evidenced in Plate 1 by light blue, corresponding to the unique Meteosat numeric count of 16, while in Plate 3 a palette of blues covers the same area, corresponding to aerosol optical thicknesses increasing from 0.13 in the north to 0.23 in the south. As discussed in the following section, this is due to the low sensitivity of the Meteosat visible sensor.

Uncertainties. One primary source of error in the determination of the aerosol optical thickness from Meteosat imagery lies in the absolute calibration of the Meteosat VIS sensor. According to Köpke [1983] the accuracy of the calibration constant $C$ was $10 \%$. However, the temporal evolution of its absolute value is unknown, and it is difficult to estimate the uncertainty in $\mathbf{1 9 8 5}$.

The use of a standard gaseous atmospheric model to take into account Rayleigh scattering and gaseous absorption of the light also generates some error. During the unusual conditions of aerosol transport from Africa, atmospheric temperature, pressure, and absorbing trace gas concentration profiles over the Mediterranean are expected to be different from standard summer mid-latitude conditions. For instance, the water vapor columnar density between ground level and $500 \mathrm{hPa}$, deduced from the atmospheric soundings performed at Ajaccio at 1200 UT from July 1 to 4 was equal to $22100,32900,31000$, and $31400 \mathrm{~g} \mathrm{~m}^{-2}$, respectively, while the standard value was 29300 $\mathrm{g} \mathrm{m}^{-2}$. However, Rayleigh scattering and gaseous absorption have only a minor contribution to the radiance at the top of the atmosphere, and the relevant relative errors are limited to $1-2 \%$. Indeed, in the absence of clouds the atmospheric aerosol content and the sea surface reflectance are clearly the most sensitive parameter on the Meteosat radiance over the sea, as confirmed by sensitivity tests. For instance, a change by a factor of 10 in $\tau_{550}$ and in the sea surface albedo, respectively, results in a 135 and $45 \%$ average increase in the computed radiance, when it is only $6 \%$ for the water vapor content.

Using another radiative transfer model, Fraser [1976] previously demonstrated that among possible errors an error of 0.01 in the sea surface albedo was likely to induce the greatest relative error $(8 \%)$ in the computed radiance. As confirmed by Meteosat images, the computed reference count for Mediterranean seawater pixels in clear conditions was 12 . However, pixels from the Strait of Gibraltar area had their numeric count at 8 in clear conditions (white area in the July 3 image, Plate 1). This can be explained by particularly high chlorophyll concentrations in summer in the Alboran Sea, causing an increase in the absorption of light by surface waters. This is due to the nutrient rich, cold Atlantic waters entering the surface Mediterranean and to the upwelling of Mediterranean waters along the Spanish coast of the Alboran Sea [Jacques and Tréguer, 1986; Morel and André, 1991]. Computations show that the sea surface albedo of the Alboran Sea should be lower than 0.011 to account for such low numeric counts. This suggests that desert dusts were actually present over the Alboran Sea on July 1 and 2 (Plate 1). As this regional variation in albedo was not taken into account in computations, $\tau_{550}$ determinations over the Alboran Sea were underestimated by at least 0.15 . However, this underestimation affected only small parts of the dust plumes on July 1 and 2.

The low sensitivity of the VIS sensor, which has only 64 digital levels, might also be an important source of error. Indeed, computations show that the Meteosat count of a Mediterranean pixel was insensitive to at least 0.10 changes in $\tau_{550}$. The lowest Meteosat numeric count value giving evidence of the presence of atmospheric dusts, 16 , corresponded to $\tau_{550}$ values ranging between 0.13 and 0.23 , depending on geometric conditions, within the respective range of $0.02-0.23$ and 0.08 0.37. This means that relative uncertainties in the determination of $\tau_{550}$ at the pixel scale may be as large as $80 \%$ or more for low turbidity conditions. However, it must be emphasized that any spatial or temporal integration would tend to cancel this source of error through an averaging effect.

We assumed that the aerosol optical thickness was only due to desert dust. Actually, the stratospheric aerosol optical thickness was particularly low at that time (about 0.01 [Michalsky et al., 1990]) and did not affect our estimation. In 

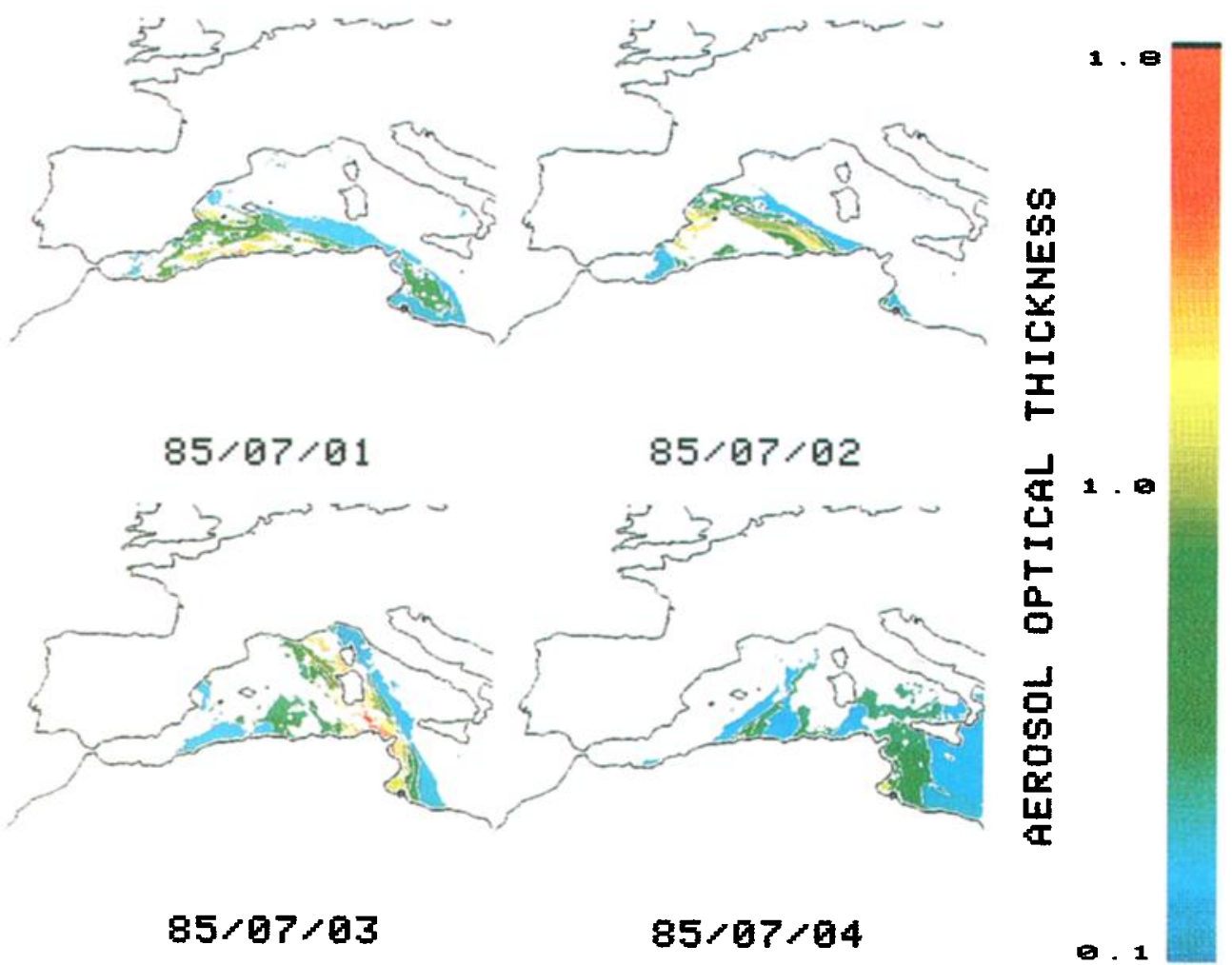

$85 / 07 \times 03$

$85 / 07 / 04$

อ. 1

Plate 3. Calculated aerosol optical thickness over the westem Mediterranean at 1145 UT from July 1 to 4, 1985.
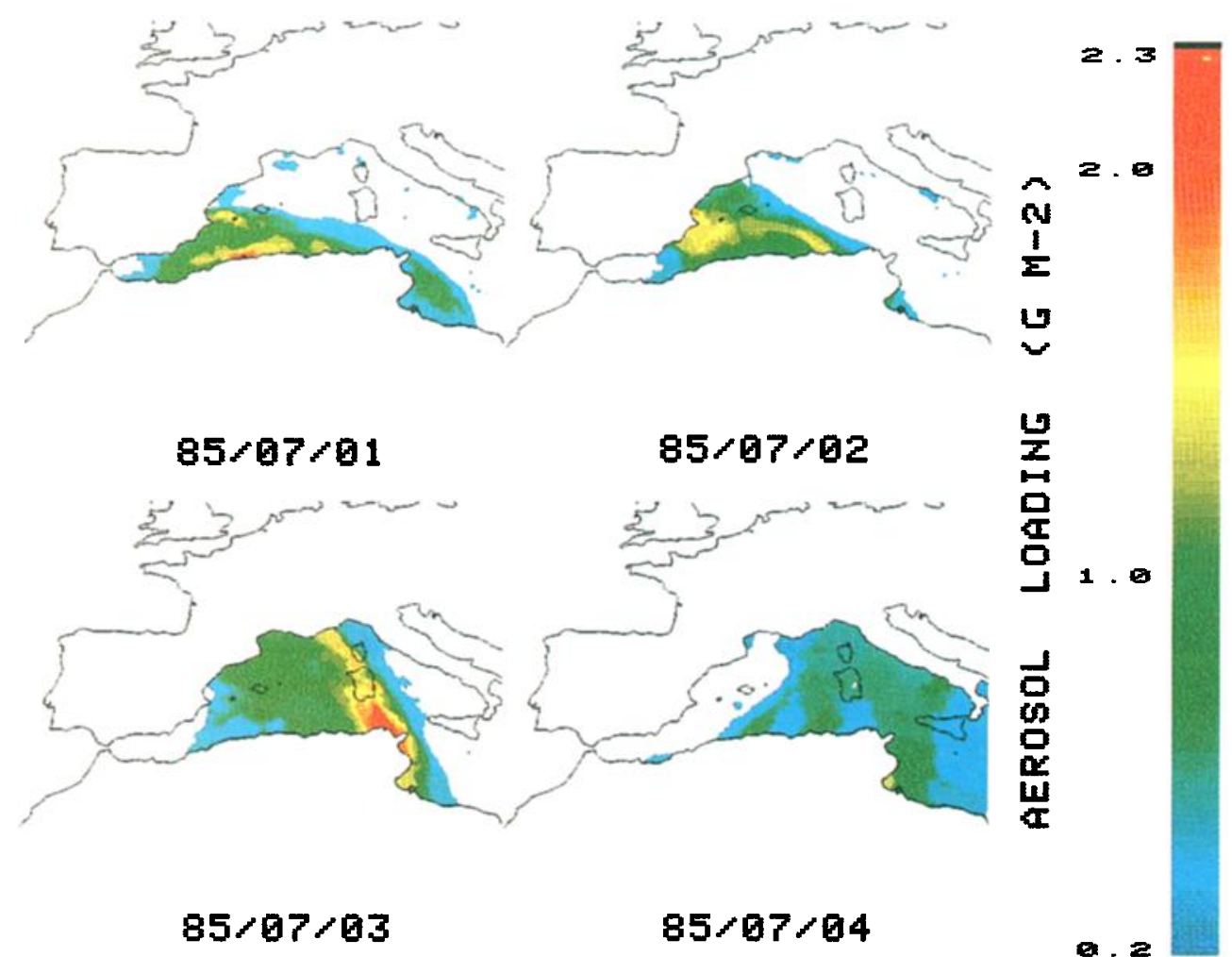

$85 / 07 / 03$

$85 / 07 / 04$

a. 2

Plate 4. Computed desen aerosol columnar density $\left(\mathrm{g} \mathrm{m}^{-2}\right.$ ) over the westem Mediterranean at 1145 UT from July 1 to 4 , 1985. 
the boundary layer, aerosol optical measurements performed in March and April 1986 at Capo Cavallo yielded background values of $\tau_{550}$ in the range $0.03-0.15$, with an average of 0.09 . Comparable atmospheric concentrations of sea-salt particles (as traced by non crustal $\mathrm{Na}$ ) and sulfate particles (as traced by non marine S) were found in March-April 1986 and June-July 1987 [Bergametti, 1987]. Haggerty et al. [1990] have also reported such background values of aerosol optical thickness at $502 \mathrm{~nm}$ measured in the Strait of Gibraltar in June 1986, ranging between 0.01 and 0.11 . Because the background value is lower than or equal to the detection limit (see above), we did not subtract it from computed values of $\tau_{550}$. The value of 0.1 can be considered as an absolute error due to the background component.

Uncertainties in the aerosol physical properties, refractive index and size distribution were another source of possible error. The value of $1.50-0.005 i$ of the refractive index seems well accepted by authors. Moreover, optical properties of both background desert aerosol models from Shettle [1984] and D'Almeida [1987] are very consistent. Jankowiak and Tanré [1992] estimated the overall relative uncertainty of the determination of $\tau_{550}$ off western Africa from Meteosat imagery using an approach similar to ours, to be about $\pm 30 \%$ for any given pixel, by comparison with ground-based measurements. We did not perform ground truth optical measurements to confirm this range of uncertainty over the Mediterranean basin. Since the relative uncertainty could be higher in our conditions due to greater uncertainty in the aerosol model after crossing the Mediterranean, we believe an overall relative uncertainty of $50 \%$ in the determination of $\tau_{550}$ has to be considered as a maximum. Once again, let us emphasize that this is the uncertainty in the value of any single pixel, so that any integration process should decrease it.

\subsection{Airborne Dust Mass}

Results. Results from our computation of desert aerosol columnar densities over the westem Mediterranean at 1145 UT from July 1 to 4, 1985, are presented in Plate 4. Values range between 0.18 and $2.30 \mathrm{~g} \mathrm{~m}^{-2}$. The interpolation is believed to give a good estimate of what would be the aerosol loading if clouds were not present and to allow us to obtain the total mass of dust transported over the sea and islands by spatial integration. Using an average of $30.4 \mathrm{~km}^{2}$ per pixel, we estimated the area covered by the dust plume over the western and central Mediterranean Sea, including islands and the mass of desert dust over the basin, on July 1 to 4,1985 , at 1145 and 1215 UT. Results are reported in Table 4. They show that the dust plume was spread over a few hundreds of thousands of square kilometers and that it was continuously expanding. The decrease in area observed between July 1 and 2 was essentially due to the eastern part of the dust plume which was present over the Gulf of Gabes on July 1 and had returned over Africa on July 2 (Plate 4), due to the southward circulation generated by the high cell over Tunisia (Figure 1). The related mass of dust transported back to Africa amounted to about $45 \times 10^{9} \mathrm{~g}$. Excluding this recycled part of the dust plume, results also indicate that the mass of dust over the basin continuously increased from July 1 to 3 , raising an amount of $580 \times 10^{9} \mathrm{~g}$.

Uncertainties. There are several assumptions in the determination of the aerosol mass from the aerosol optical thickness, and it is worth summarizing the numerous uncertainties in the process. As previously mentioned in section 3.3, the proportionality coefficient $R$ in (6) appeared to be a great source of error in our determination of the columnar aerosol mass $\boldsymbol{M}$. Given our previous observations from cascade impactor aerosol samples and results on the deposition velocity of particles (see section 4.2), the value of 1.3 of the conversion factor $R$ appeared to be the best choice. Nevertheless, for a given aerosol optical thickness there is a difference of approximately a factor of 2 between the values of $M$ calculated from the Shettle [1984] and D'Almeida [1987] background desert aerosol models (Table 2), although their respective optical properties are very close to each other. The overall MMD of Shettle's and D'Almeida's background desert aerosol model are 3.80 and $4.71 \mu \mathrm{m}$, respectively. Indeed, dust particles of more than $5 \mu \mathrm{m}$ in diameter account for about $45 \%$ of the aerosol mass of both models, while they have almost no influence on $\tau_{550}$. Moreover, there is almost a factor of 3 difference between the value of $R$ of 1.3 , obtained in this work using Shettle's model, and the value of 3.75 from Carlson and Caverly [1977], derived from field measurements on Sal, Cape Verde Islands, $600 \mathrm{~km}$ offshore from Senegal. Indeed, the data discussed by Carlson and Caverly suggest that a major fraction of the dust mass in the Saharan air layer over the Atlantic consists of particles greater than $10 \mu \mathrm{m}$ in diameter. The distance of Sal from West African dust source regions is roughly comparable to the distance of Corsica from North African dust source regions, so that the value of 3.75 could apply in the northwestern Mediterranean. Although the source regions and the meteorological conditions of transport toward the Atlantic and the Mediterranean are different, we emphasize again that investigations of particle size distributions in several samples of aerosol, rain, snow, and in a dry deposition sample confirm that such large particles are present over the Mediterranean during high dust episodes from Africa (see section 3.2, "aerosol model" subsection). It seems therefore that the value of 1.3 of the conversion factor might be significantly underestimated. Unfortunately, direct confirmation of the aerosol model is impossible due to the absence of size distribution data for particles of more than $10 \mu \mathrm{m}$ diameter which results from the technical difficulty of sampling such particles.

It should also be kept in mind that all the previously discussed values of the ratio $R$ were determined assuming spherical particles with a bulk density of $2.5 \mathrm{~g} \mathrm{~cm}^{-3}$, which is a common assumption when dealing with atmospheric dustlike particles [e.g., Fraser, 1976; Carlson and Caverly, 1977; Arimoto et al., 1985; D'Almeida, 1986; Giorgi, 1988;

TABLE 4. Computed Area ofExtent of the Dust Plume Over the Westem and Central Mediterranean Sea Including Islands and Related Mass of Suspended Desert Dust, From July 1 to 4, 1985

\begin{tabular}{cccl}
\hline Date & Hour, UT & Area, $10^{3} \mathrm{~km}^{2}$ & Mass, $10^{9} \mathbf{g}$ \\
\hline July 1, 1985 & 1145 & $498(377)$ & $309(259)$ \\
July 1, 1985 & 1215 & $517(395)$ & $330(276)$ \\
July 2, 1985 & 1145 & $393(372)$ & $300(294)$ \\
July 2, 1985 & 1215 & $412(385)$ & $314(305)$ \\
July 3, 1985 & 1145 & 735 & 574 \\
July 3, 1985 & 1215 & 752 & 580 \\
July 4, 1985 & 1145 & 866 & 379 \\
July 4, 1985 & 1215 & 882 & 418
\end{tabular}

On July 1 and 2, numbers in parentheses do not include the eastem part of the dust plume present over the Gulf of Gabes. On July 4 the dust plume was further extending over the eastem Mediterranean (Plates 1 and 3). 
Joussaume, 1990]. Indeed, Bücher et al. [1983] have measured a density of 2.53 from a sample of Saharan dust deposited in the Pyrenees in August 1980. However, the bulk densities of common clay minerals range from 2.0 to $2.6 \mathrm{~g} \mathrm{~cm}^{-3}$ [Caillère and Hénin, 1963]. Moreover, atmospheric dust particles are not actual spheres, and the shape factor of particles is particularly influential on mass calculations and on scattering properties, mainly for backscattered conditions as in our case, so that the values of $\boldsymbol{R}$ previously discussed might be overestimated by up to $100 \%$ due to error in shape and density of particles.

Finally, when combining all uncertainties, the columnar atmospheric mass loading at the pixel scale was probably estimated in this work within the relative limits $-70 \%$ and $+300 \%$. Integrating the dust mass over the basin was likely to reduce significantly the overall uncertainty by averaging the local errors, but the possible presence of residual pixels contaminated by water or ice cloud could have lead to an overestimation of the result. Visual examination of filtered images suggested that contamination was minimized, as confirmed by the homogeneous structure of interpolated aerosol loading fields (Plate 3 ), but partially cloud covered areas could have not been totally excluded. Moreover, the interpolation step was likely to introduce further uncertainty in the total mass of dust calculated over the basin. Indeed, the mass from interpolated pixels accounts for 45 to $75 \%$ of the total, so that the overall accuracy of the total dust mass determination is estimated to be about a factor of 3 .

\subsection{Total Mass of Dust Exported From Africa}

Averaging the atmospheric dust load over Corsica during the estimated deposition period yielded about $0.4 \mathrm{~g} \mathrm{~m}^{-2}$ (within a factor of 3). By comparison with the mean deposition of $0.1 \mathrm{~g}$ $\mathrm{m}^{-2} \mathrm{~d}^{-1}$ (see section 4.2 ), it turned out that an average of $25 \%$ of the dust would have been removed per day. Given this daily settling rate and the airborne dust mass calculations (Table 4), we calculated that an amount of about $0.4 \times 10^{12} \mathrm{~g}$ of dust was deposited to the sea. Given the export of dust to continental Europe, as evidenced by Plates 1 and 4, it was roughly estimated that a total of $10^{12} \mathrm{~g}$ of dust was exported from Africa during this transport event.

Three other similar episodes of dust transport from Africa, with comparable peaks of daily atmospheric concentrations and no precipitation, have been observed in Corsica in July 1985 [Bergametti, 1987]. Thus one can roughly estimate that about 4 $x 10^{12} \mathrm{~g}$ of dust was transported northward over the western Mediterranean from Africa during this month. D'Almeida's [1986] model calculations of Saharan dust export toward Europe in July 1981 and July 1982 were significantly larger, although he did not include North African source regions: $11.5 \times 10^{12} \mathrm{~g}$ and $33.1 \times 10^{12} \mathrm{~g}$, respectively. But these computations include export to the entire Mediterranean and the northern Atlantic. Indeed, Saharan dust transport toward Europe can also occur via the Atlantic Ocean and the eastern Mediterranean [e.g. Oliva et al., 1983; Chester et al., 1984; Scorer, 1986; Reiff et al., 1986; Glavas, 1988], but dust plumes reaching Corsica between February 1985 and April 1986 were always found to come directly from Africa over the western Mediterranean and sometimes over Spain [Bergametti, 1987]. Using an average deposition rate, Bücher and Lucas [1984] roughly estimated that only $10^{12} \mathrm{~g} \mathrm{yr}^{-1}$ of Saharan dust were deposited over the whole Europe, while D'Almeida's [1989] computation of average northem export (Atlantic plus Mediterranean) from Sahara over 1981 and 1982 was $99 \times 10^{12} \mathrm{~g} \mathrm{yr}^{-1}$. The sporadicity of such events and the year-to-year variability of dust production and transport make difficult to compare these numbers. However, given the range of uncertainties of the different estimation methods, they appear to be consistent with each other.

\subsection{Comparison Between Dust Removal Rates Derived From Remote Sensing and Ground-Based Data}

Taking into account the daily settling rate of $25 \%$ of the atmospheric dust mass during the transport and assuming a $3500- \pm 500-\mathrm{m}$ average thickness for the dust layer over Corsica (Table 3) yielded an apparent scavenging velocity of the dust particles from the dust layer of $1.0 \mathrm{~cm} \mathrm{~s}^{-1}$, within the possible range $0.29-3.5 \mathrm{~cm} \mathrm{~s}^{-1}$, including uncertainties on the average atmospheric load and average thickness of the dust layer. Despite this range this net vertical transfer velocity is lower than the deposition velocity of particles to seawater, controlled by gravitational settling, which was measured at 7.7 $\mathrm{cm} \mathrm{s}^{-1}$ using a surrogate surface (see section 4.2). Either our aerosol model [Shettle, 1984] underestimates the contribution of large particles or the gravitational settling of particles during transport is very limited. As discussed in section 4.2, it is not likely that this aerosol model underestimates the mass of large particles, since the dry deposition velocity to surface seawater calculated using the Slinn and Slinn [1980] model was found to be $6.9 \mathrm{~cm} \mathrm{~s}^{-1}$. Moreover, reported observations of very long range transport of giant mineral aerosol particles (see section 3.2), contradicting model calculations [e.g., Schütz, 1979], strongly suggest that the scavenging of particles out from dust plumes is limited by physical mechanisms. Indeed, the air mass trajectories reported in Figure 2 and 3 indicate that the African air layer was subject to a synoptic upward movement of 1.5 to $2 \mathrm{~cm} \mathrm{~s}^{-1}$ over the basin, likely to limit the gravitational settling of dust particles. Assuming that gravitational settling was only limited by this process yields a downward gravitational deposition velocity of dust particles averaging $2.5-3 \mathrm{~cm} \mathrm{~s}^{-1}$, within the possible range $1.8-5.5 \mathrm{~cm} \mathrm{~s}^{-1}$. Moreover, upward air movements due to small scale convection processes associated with clouds [Gage et al., 1990] may further limit the downward transfer of particles. Therefore the method used in this work for assessing the mass of atmospheric desert dust over the sea from Meteosat data produced results consistent with our field measurements.

\section{Conclusions}

This work was focused on the use of Meteosat VIS data to estimate the mass of desert dust over the western Mediterranean during a transport event which occurred in early July 1985. A method based on a desert aerosol model and an Earthatmosphere radiative transfer model was developed to calculate aerosol optical depth over the sea from Meteosat VIS data. The cloud-contaminated pixels of Meteosat images as well as pixels over islands were discarded, and masked pixels were interpolated for integrating the atmospheric load over the basin. The desert aerosol optical thickness was found to range between 0.1 and 1.8. A proportionality coefficient of 1.3 was computed between the aerosol mass in grams per square meter and the aerosol optical depth. Despite indirect validation of the aerosol model used, the lack of knowledge of the actual masssize distribution of suspended dust particles was found to be the accuracy-limiting factor. This points out the need for accurate characteristics of mass-particle size distributions of long range transported desert aerosols, especially over $10 \mu \mathrm{m}$ in diameter, emphasizing the need for adequate techniques of measurements that has already been mentioned [Dulac et al., 1989]. The mass 
of atmospheric particles from Africa present over the basin was estimated to reach about $0.6 \times 10^{12} \mathrm{~g}$ at the maximum and the total mass of dust exported from Africa to approximate to $10^{12}$ g. Taking thoroughly into account uncertainties, we estimated that such results were accurate to within a factor of \pm 3 . Finally, we estimated a daily scavenging rate of $25 \%$ of the suspended dust mass over Corsica, a dry deposition to the sea of $0.4 \mathrm{x}$ $10^{12} \mathrm{~g}$, a net transfer velocity of particles from the dust layer of approximately $1 \mathrm{~cm} \mathrm{~s}^{-1}$, and a dry deposition velocity of particles to seawater of about 7 to $8 \mathrm{~cm} \mathrm{~s}^{-1}$. The former result was derived from the comparison between vertically integrated atmospheric load and deposition at the ground level, the latter from observations at the ground level only. This net transfer velocity results from the combination of the settling of dust particles with the competing synoptic upward movement of the associated African air mass, which was found to be uplifted over the basin at a velocity of the order of $2 \mathrm{~cm} \mathrm{~s}^{-1}$. Given the large uncertainties in computation that were shown, the overall consistency between model computations from satellite data and results from ground-based measurements is considered as a validation of the method used in this work.

Acknowledgments. We wish to thank the staff of the signal station of Capo Cavallo for their logistical support in Corsica. We also thank the French Marine Nationale for the free access to the signal station and the French Direction of Météo-France, Ministère des Transports, for the use of the meteorological tower at Capo Cavallo. We are grateful to B. Strauss, D. Martin, and J.-M. Gros, Service des Etudes Spéciales de Météo-France, for providing air mass trajectories, to Ms E. Bon Nguyen and B. Chatenet for drawing figures, to R. Arimoto for grammatical review and to anonymous reviewers for helpful comments. This work was supported by the Centre National de la Recherche Scientifique and the Commissariat à l'Energie Atomique and by grants from the PIREN/CNRS ATP "Atrosols Désertiques" and program "Erosion Eolienne en Région Arides et Semi-Arides" and from the Programme National de Télédétection Spatiale. This is CFR contribution 1167.

\section{REFERENCES}

Arimoto, R., R. A. Duce, B. J. Ray, and C. K. Unni, Atmospheric trace elements at Enewetak Atoll, 2, Transport to the ocean by wet and dry deposition, J. Geophys. Res., 90, 2391-2408, 1985.

Amold M., A. Seghaier, D. Martin, P. Buat-Ménard, and R. Chesselet, Geochemistry of the marine aerosol over the western Mediterranean Sea, paper presented at 6th Joumées d'Etudes sur les Pollutions Marines en Méditerranée, Comm. Int. pour l'Explor. Sci. de la Mediter., pp. 27-37, Monaco, 1982.

Bergametti, G., Apports de matière par voie atmosphérique à la Méditerranée occidentale: Aspects géochimiques et métécologiques, thèse d'état, Univ. of Paris VII, 1987.

Bergametti, G., A. L. Dutot, P. Buat-Ménard, R. Losno, and E. Remoudaki, Seasonal variability of the elemental composition of atmospheric aerosol particles over the northwestem Mediterranean, Tellus, 41(B), 353-361, $1989 a$

Bergametti, G., L. Gomes, E. Remoudaki, M. Desbois, D. Martin, and P. Buat-Ménard, Present transport and deposition pattems of African dusts to the northwestern Mediterranean, in Paleoclimatology and Paleometeoro-logy: Modern and Past Patterns of Global Atmospheric Transport, edited by M. Leinen and M. Samthein, pp. 227-252, Kluwer Academic, Boston, Mass., 1989 b.

Betzer, P. R., et al., Long-range transport of giant mineral aerosol particles, Nature, 336, 568-571, 1988.

Bowen, H. J. M., Trace Elements in Biochemistry, Academic, San Diego, Calif., 1966.
Buat-Ménard, P., and R. Chesselet, Variable influence of the atmospheric flux on the trace metal chemistry of oceanic suspended matter, Earth Planet. Sci. Lett., 42, 399-411, 1979.

Buat-Ménard, P., J. Davies, E. Remoudaki, J. C. Miquel, G. Bergametti, C. E. Lambert, U. Ezat, C. Quetel, J. La Rosa, and S. W. Fowler, Non-steady-state biological removal of atmospheric particles from Mediterranean surface waters, Nature, 340, 131-134, 1989.

Bücher, A., and C. Lucas, Poussières Africaines sur l'Europe, Meteorologie, V-33, 53-69, 1975.

Bücher, A., and C. Lucas, Sédimentation éolienne intercontinentale, poussières sahariennes et géologie, Bull. Cent. Rech. Explor. Prod. Elf Aquitaine, 8, 151-165, 1984.

Bücher, A., J. Dubief and C. Lucas, Retombées estivales de poussières sahariennes sur l'Europe, Rev. Geol. Dyn. Géogr. Phys., 24, 153165, 1983.

Caillère, S., and S. Hénin, Minéralogie des Argiles, 355 pp., Masson, Paris, 1963.

Carder, K. L., R. G. Steward, and P. R. Betzer, Dynamics and composition of particles from an aeolian input event to the Sargasso Sea, J. Geophys. Res., 91, 1055-1066, 1986.

Carlson, T. N., Atmospheric turbidity in Saharan dust outbreaks as detemined by analysis of satellite brightness data, Mon. Weather Rev., 107, 322-355, 1979.

Carlson, T. N., and R. S. Caverly, Radiative characteristics of Saharan dust at solar wavelengths, J. Geophys. Res., 82, 3141-3152, 1977.

Chester, R., E. J. Sharples, G. S. Sanders, and A. C. Saydam, Saharan dust incursion over the Thynthenian Sea, Atmos. Environ., 18, 929 935, 1984.

Coackley, J. A., and F. P. Bretherton, Cloud cover from high-resolution scanner data: Detecting and allowing for partially filled fields of view, J. Geophys. Res., 87, 4917-4932, 1982.

Corregiari, A., S. Guerzoni, R. Lenaz, G. Quarantotto, and G. Rampazzo, Dust deposition in the central Mediterranean (Thyrmenian and Adriatic seas): Relationships with marine sediments and riverine input, Terra Nowa, 1, 549-558, 1990.

Coude-Gaussen, G., Local, proximal and distal Saharan dusts: Characterization and contribution to the sedimentation, in Paleoclimatology and Paleometeorology: Modern and Past Patterns of Global Atmospheric Transport, edited by M. Leinen and M. Samthein, pp. 339-358, Kluwer Academic, Boston, Mass., 1989.

Coude-Gaussen, G., P. Rognon, G. Bergametti, L. Gomes, B. Strauss, J. M. Gros, and M. N. Le Coustumer, Saharan dust on FuerteVentura Island (Canaries): Chemical and mineralogical characteristics, air mass trajectories, and probable sources, J. Geophys. Res., 92, 9753-9771, 1987.

D'Almeida, G. A., A model for Saharan dust transport, J. Clim. Appl. Meteorol., 25, 903-916, 1986.

D'Almeida, G. A., On the variability of desert aerosol radiative characteristics, J. Geophys. Res., 92, 3017-3026, 1987.

D'Almeida, G. A., Desert aerosol: Characteristics and effects on climate, in Paleoclimatology and Paleometeorology: Modern and Past Patterns of Global Almospheric Transport, edited by M. Leinen and M. Samthein, pp. 311-338, Kluwer Academic, Boston, Mass., 1989.

Duce, R. A., C. K. Unni, B. J. Ray, J. M. Prospero, and J. T. Merrill. Long-range atmospheric transport of soil dust from Asia to the tropical North Pacific: Temporal variability, Science, 209, 15221524, 1980.

Dulac, F. Dynamique du transport et des retombées d'aérosols métalliques en Méditerranée occidentale, Ph.D. thesis, Univ. of Paris VII, 1986.

Dulac, F., P. Buat-Ménard, M. Amold, and U. Ezat, Atmospheric input of trace metals to the western Mediterranean Sea: Factors 
controlling the variability of atmospheric concentrations, $J$ Geophys. Res., 92, 8437-8453, 1987.

Dulac, F., P. Buat-Ménard, U. Ezat, S. Melki, and G. Bergametti, Atmospheric input of trace metals to the western Mediterranean: Uncertainties in modeling dry deposition from cascade impactor data, Tellus, 41 (B), 362-378, 1989.

Dulac, F., G. Bergametti, E. Remoudaki, L. Gomes, U. Ezat, and P. BuatMenard, Dry deposition of aerosol particles in the marine atmosphere: a critical evaluation of current field and modeling approaches, paper presented at the Sth International Conference on Precipitation Scavenging and Atmosphere-Surface Exchange Processes, Richland, Washington, July 15-19, in press, 1991.

European Space Operation Center (ESOC), Magnetic tapes and files description, in Meteosat System Guide, vol. 12, Darmstadt, Germany, 1987.

Fraser, R. S., Satellite measurement of mass of Sahara dust in the atmosphere, Appl. Opt., 15, 2471-2479, 1976.

Fraser, R. S., Y. J. Kaufman, and R. L. Mahoney, Satellite measurement of aerosol mass and transport, Almos. Environ., 18, 2577-2584, 1984.

Fujita, T.T., Applications of ATS III photographs for determinations of dust and cloud velocities over the northern tropical Allantic, Satellite and Mesometeorology Research Project, Res. Pap. 90, Dep. of Geophys. Sci., Univ. of Chicago, 1970.

Gage, K. S., B. B. Balsley, L. Ecklund, R. F. Woodman, and S. K. Avery, Wind-profiling Doppler radars for tropical atmospheric research, Eos Trans. AGU, 71, 1851-1854, 1990.

Giorgi, F., Dry deposition velocities of atmospheric aerosols as inferred by applying a particle dry deposition parametrization to a general circulation model, Tellus, 40(B), 23-41, 1988.

Glavas, S., A wet-only precipitation study in a Mediterranean site, Patras, Greece, Atmos. Environ., 22, 1505-1507, 1988.

Gomes, L., G. Bergametti, F. Dulac, and U. Ezat, Assessing the actual size distribution of atmospheric aerosols collected with a cascade impactor, J. Aerosol Sci., 21, 47-59, 1990.

Griggs, M., Measurements of atmospheric aerosol optical thickness over water using ERTS-1 data, J. Air Pollut. Control Assoc., 25, 622-626, 1975.

Griggs, M., Satellite observations of atmospheric aerosols during the EOMET cruise, J. Almos. Sci., 36, 695-698, 1979.

Guerzoni, S., G. Cesari, R. Lenaz, and L. Cruciani, A new sampling station at the coastal site of Capo Carbonara (Sardinia, Central Mediterranean): Preliminary data and technical proposal, Report of the Second WMO/UNEP Workshop on Airbome Pollution of the Mediterranean, Monaco, April 8-12, 1991, MAP Tech. Rep. Ser. in press, 1991.

Haggerty, J. A., P. A. Durkee, and B. J. Wattle, A comparison of surface and satellite-derived aerosol measurements in the westem Mediterranean, J. Geophys. Res., 95, 1547-1557, 1990.

Iwasaka, Y., H. Minoura, and K. Nagaya, The transport and spatial scale of Asian dust-storm clouds: A case study of the dust-storm event of April 1979, Tellus, 35(B), 189-196, 1983.

Jacques, G., and P. Tréguer, Ecosystèmes Pélagiques Marins, Chapter La Méditerranée occidentale, pp. 167-226, Masson, Paris, 1986.

Jaenicke, R., Aerosol physics and chemistry, in Landolt-Börnstein Numerical Data and Functional Relationships in Science and Technology. V, 4b, edited by G. Fischer, pp. 391-457, SpringerVerlag, New York, 1987.

Jaenicke, R., and L. Schütz, Comprehensive study of physical and chemical properties of the surface aerosols in the Cape Verde Islands region, J. Geophys. Res., 83, 3585-3599, 1978.

Jankowiak, I., and D. Tanré, Climatology of Saharan dust events observed from Meteosat Imagery over oceans, Method and preliminary results, J. Clim., in press, 1992.
Joussaume, S., Three-dimensional simulations of the atmospheric cycle of desert dust particles using a general circulation model, $J$. Geophys. Res., 95, 1909-1941, 1990.

Kästner, M., P. Köpke, and H. Quenzel, Monitoring of Saharan dust over the Atlantic using Meteosat-Vis-data, Adv. Space Res., 2, 119 $121,1983$.

Knap, A. H., The long-range atmospheric transport of natural and contaminant substances, NATO ASI Ser., Ser. C297, 321 pp., Kluwer Academic, Boston, Mass., 1990.

Kneizys, F. X., E. P. Shettle, W. O. Gallery, J. H. Chetwynd Jr, L. W. Abreu, J. E. A. Selby, R. W. Fenn, and R. A. Mc Clatchey, Atmospheric transmittance/radiance: Computer code LOWTRAN 5, AFGLTech. Rep. AFGL-TR-80-0067, 233 pp., 1980.

Köpke, P., Calibration of the Vis-channel of Meteosat-2, Adv. Space Res., 2, 93-96, 1983.

Legrand, M., J. J. Bertrand, and M. Desbois, Dust clouds over West Africa: A characterization by satellite data, Ann. Geophys., 3, 777 . 784, 1985.

Losno, R., G. Bergametti, and G. Mouvier, Determination of optima conditions for atmospheric aerosol analyses by $\mathrm{X}$-ray fluorescence, Environ. Tech. Lett., 8, 77-87, 1987.

Losno, R., G. Bergametti, and P. Buat-Ménard, Zinc partitioning in Mediterranean rainwater, Geophys. Res. Lett., 15, 1389-1392,1988.

Loÿe-Pilot, M. D., J. M. Martin, and J. Morelli, Influence of Saharan dust on the rain acidity and atmospheric input to the Mediterranean, Nature, 321, 427-428, 1986.

Martin, J. H., and S. E. Fitzwater, Iron deficiency limits phytoplankton growth in the north-east Pacific subarctic, Nature, 331, 341-343, 1988.

Martin, D., C. Mithieux, and B. Strauss, Evaluation of the use of the synoptic vertical component in a trajectory model, Atmos. Environ., 21, 45-52, 1987.

Martin, D., G. Bergametti, and B. Strauss, On the use of the synoptic vertical velocity in trajectory model: Validation by geochemical tracers, Almos. Environ., 24(A), 2059-2069, 1990.

Mc Clatchey, R. A., R. W. Fenn, J. E. A. Selby, F. E. Volz, and J. S. Garing, Optical properties of the atmosphere, Rep. AFCRL-TR-710279, Environ. Res. Pap. 354 , Air Force Cambridge Res. Lab., Bedford, Mass., 1971.

Mekler, Y., H. Quenzel, G. Ohring, and I. Marcus, Relative atmospheric aerosol content from ERTS observations, J. Geophys. Res., 82, 967-970, 1977.

Meteosat Exploitation Project (MEP), Meteosat-2 calibration report: July-September 1985, Rep. 13 , Europ. Space Oper. Cent., Europ. Space Agency, Damstadt, Germany, 1985.

Michalsky, J. J., E. W. Pearson, and B. A. Le Baron, An assessment of the impact of volcanic eruptions on the northern hemisphere's aerosol burden during the last decade, J. Geophys. Res., 95, 56775688, 1990.

Middleton, N. J., A. S. Goudie, and G. L. Wells, The frequency and source areas of dust storms, in Aeolian Geomorphology, edited by W. G. Nickling, pp. 237-259, Allen and Unwin, Winchester, Mass., 1986.

Morel, A., and J.-M. André, Pigment distribution and potential primary production in the westem Mediterranean, as derived from space (CZCS observations), J. Geophys. Res., 96, 12,685-12,698, 1991.

Morgan, M., Introduction to the Meteosat System, Europ. Space Oper. Cent., Europ. Space Agency, Damstadt, Gemany, 1981.

Oliva, P., G. Coudé-Gaussen, H. Delannoy, L. Dorize, P. Rognon, and M. Tabeaud, Etude de la dynamique de quelques lithométéores sahariens par télédétection spatiale, Mediter. Teledetection, 3, 2151, 1983.

Patterson, E. M., D. A. Gillette, and B. H. Stockton, Complex index of 
refraction between 300 and $700 \mathrm{~nm}$ for Saharan aerosols, J. Geophys. Res., 82, 3153-3160, 1977.

Peters, A., Peters Atlas of the World, 231 pp., Longmans Green, Toronto, Ont., 1989.

Pitty, A. F., Particle size of the Saharan dust which fell in Britain in July 1968, Nature, 220, 364-365, 1968.

Prodi, F., and G. Fea, A case of transport and deposition of Saharan dust over the Italian peninsula and southern Europe, J. Geophys. Res., 84, 6951-6960, 1979.

Prospero, J. M., Mineral-aerosol transport to the North Atlantic and North Pacific: The impact of African and Asian sources, in The Long-Range Atmospheric Transport of Natural and Contaminant Substances, edited by A. H. Knap, pp. 59-86, Kluwer Academic, Boston, Mass., 1990.

Prospero, J. M., E. Bonatti, C. Schubert, and T. N. Carlson, Dust in the Caribbean atmosphere traced to an African dust storm, Earth Planet Sci. Lett., 9, 287-293, 1970.

Rahn, K. A., The chemical composition of the atmospheric aerosol, Tech. Rep., 275 pp., Univ. of R. I., Kingston, 1976.

Rao, C. R. N., L. L. Stowe, E. P. Mc Clain, and J. Shapper, Development and application of aerosol remote sensing with AVHRR data from NOAA satellites, in Aerosols and Climate, edited by P. V. Hobbs and M. P. Mc Cormick, Pp. 69-79, A. Deepak, Hampton, Va., 1988.

Reiff, J., G. S. Forbes, F.T. M. Spieksma, and J. J. Reynders, African dust reaching northwestem Europe: A case study to verify trajectory calculations, J. Clim. Appl. Meteorol., 25, 1543-1567, 1986.

Remoudaki, E., Etude des processus contrôlant la variabilité temporelle des flux atmosphériques de polluants et de poussières minérales en Méditerranée occidentale, Ph.D. thesis, Univ. of Paris VII, 1990.

Saunders, R. W., and K. T. Kriebel, An improved method for detecting clear sky and cloudy radiances from AVHRR data, Int. J. Remote Sens., 9, 123-150, 1988.

Schiffer, R. A., and W. B. Rossow, The Intemational Satellite Cloud Climatology Project (ISCCP): The first project of the World Climate Research Programme, Bull. Am. Meteorol. Soc., 64, 779-784, 1983.

Schneider, B., N. W. Tindale, and R. A. Duce, Dry deposition of Asian mineral dust over the central North Pacific, J. Geophys. Res., 95, 9873-9878, 1990.

Schütz, L., Sahara dust transport over the North Allantic Ocean Model calculations and measurements, in Saharan Dust, edited by C. Morales, pp. 267-277, John Wiley, New York, 1979.

Scorer, R., Cloud Investigation by Satellite, John Wiley, New York, 1986.

Shenk, W. E., and R. J. Curran, The detection of dust storms over land and water with satellite visible and infrared measurements, Mon. Weather Rev., 102, 830-837, 1974.

Shettle, E. P., Optical and radiative properties of a desert aerosol model, in Proceedings of the Symposium on Radiation in the Almosphere, edited by G. Fiocco, pp. 74-77, A. Deepak, Hampton, Va., 1984.

Sirocko, F., and M. Samthein, Wind-borne deposits in the northwestem Indian Ocean: Record of Holocene sediments versus modem satellite data, in Paleoclimatology and Paleometeorology: Modern and Past Patterns of Global Almospheric Transport, edited by M. Leinen and M. Samthein, pp. 401-433, Kluwer Academic, Boston, Mass., 1989.

Slinn, W. G. N., Air to sea transfer of particles, in Air-Sea Exchange of Gases and Particles, edited by P. S. Liss and W. G. N. Slinn, Pp. 299-396, D. Reidel, Norwell, Mass., 1983.

Slinn, S. A., and W. G. N. Slinn, Prediction for particle deposition on natural waters, Atmos. Environ., 14, 1013-1016, 1980.

Tanré, D., and M. Legrand, On the satellite retrieval of Saharan dust optical thickness over land: Two different approaches, $J$. Geophys. Res., 96, 5221-5227, 1991.

Tanré, D., C. Deroo, P. Duhaut, M. Herman, J.-J. Morcrette, J. Perbos, and P.-Y. Deschamps, Simulation of the Satellite Signal in the Solar Spectrum (5S): User's Guide, 264 pp., Laboratoire d'Optique Atmosphérique, Université des Sciences et Techniques de Lille, Villeneuve d'Ascq, France, 1986.

Tanre, D., P.Y. Deschamps, C. Devaux, and M. Herman, Estimation of Saharan aerosol optical thickness from blurring effects in thematic mapper data, J. Geophys. Res., 93, 15,955-15,964, 1988 a.

Tanré, D., C. Devaux, M. Herman, R. Santer, and J.-Y. Gac, Radiative properties of desert aerosols by optical ground-based measurements at solar wavelengths, J. Geophys. Res., 93, 14,223-14,231, $1988 b$.

Tanre D., C. Deroo, P. Duhaut, M. Herman, J. J. Morcrette, J. Perbos, and P.Y. Deschamps, Description of a computer code to simulate the satellite signal in the solar spectrum: the $5 \mathrm{~S}$ code, Int. J. Remote Sens., 2, 659-668, 1990.

Tomadin, L., R. Lenaz, V. Landuzzi, A. Mazzucotelli, and R. Vannucci, Wind-blown dusts over the central Mediterranean, Oceanol. Acta, 7 , 13-23, 1984.

Uematsu, M., R. A. Duce, and J. M. Prospero, Deposition of atmospheric mineral particles in the North Pacific Ocean, $J$. Atmos. Chem., 3, 123-138, 1985.

UNIRAS, AGL/Interpolations: User Guide and Reference Manual, Uniras, Søborg, Denmark, 1988.

UNIRAS, AGS/Unimap 2000: Users Manual, Uniras, Søborg, Denmark, 1989.

Vinogradov, A. P., The Geochemistry of Rare and Dispersed Chemical Elements in Soils, 2nd ed., Consultants Bureau, New York, 1959.

Viollier, M., Télédétection des concentrations de seston et pigments chlorophylliens contenus dans l'océan, thèse d'état 503, Univ. of Lille, France, 1980.

Volz, F., Spectral skylight and solar radiance measurements in the Caribbean: Marine and Saharan dust, J. Atmos. Sci., 27, 10411047, 1970.

Waggoner, A. P., and R. E. Weiss, Comparison of fine particle mass concentration and light scattering extinction in ambient aerosol, Almos. Environ., 14, 623-626, 1980.

World Climate Programme (WCP), Aerosols and their climatic effects, Ser. Rep. 55, edited by A. Deepak and H. E. Gerber, 107 pp., Int. Counc. of Sci. Unions and World Meteorol. Organ., Geneva, 1983.

World Climate Programme (WCP), A preliminary cloudless standard atmosphere for radiation computation, Ser. Rep. 112, 53 pp., Int. Counc. of Sci. Unions and World Meteorol. Organ., Geneva, 1986.

G. Bergametti, Laboratoire de Physico-Chimie de l'Atmosphère, Université de Paris VII, 2 Place Jussieu, 75251 Paris Cedex 05, France.

P. Buat-Ménard and F. Dulac, Centre des Faibles Radioactivités, Centre National de la Recherche Scientifique/Commissariat l'Energie Atomique, 91198 Gif-sur-Yvette Cedex, France.

M. Desbois, Laboratoire de Météorologie Dynamique, Ecole Polytechnique, 91128 Palaiseau Cedex, France.

D. Sutton, Department of Computcr Science, Birkbeck College, Malet Street, London WC1E 7HX, England.

D. Tanré, Laboratoire d'Optique Atmosphérique, Université des Sciences et Techniques de Lille, 59655 Villeneuve d'Ascq Cedex, France.

(Received November 16, 1990; revised September 20, 1991; accepted September 20, 1991) 